\title{
Effect of Vanadium on the Uptake and Distribution of Organic and Inorganic Forms of Iodine in Sweetcorn Plants during Early-Stage Development
}

\author{
Marlena Grzanka ${ }^{1, *(\mathbb{D})}$, Sylwester Smolen ${ }^{1}$ (i) and Peter Kováčik ${ }^{2}$ \\ 1 Unit of Plant Nutrition, Institute of Plant Biology and Biotechnology, Faculty of Biotechnology and \\ Horticulture, University of Agriculture in Krakow, 31-425 Kraków, Poland; sylwester.smolen@urk.edu.pl \\ 2 Department of Agrochemistry and Plant Nutrition, Slovak University of Agriculture in Nitra-Slovenska \\ Posnohospodarska Univerzita v Nitre, 94976 Nitra-Chrenová, Slovakia; peter.kovacik@uniag.sk \\ * Correspondence: marlena.grzanka@student.urk.edu.pl
}

Received: 24 September 2020; Accepted: 19 October 2020; Published: 28 October 2020

check for updates

\begin{abstract}
Iodine and vanadium are elements that are closely related to organisms in water environments. Iodine and vanadium are known as "beneficial elements" that stimulate the growth and development of higher plants. Iodine is an essential element for the synthesis of the thyroid hormones triiodothyronine and thyroxine in the human body, with vanadium also known to be involved in the synthesis of thyroid hormones. The cooperation of both elements in the human body and in algae presents a question regarding the impact of vanadium interaction on iodine uptake in higher plants. The absorption of iodine from seawater in algae is known to be more efficient in the presence of vanadium, with key role in this process played by the iodoperoxidase enzyme, with vanadium acting as a cofactor. The study of the nature of the absorption of iodine by higher plants, and in particular by crops such as corn, remains insufficiently studied. The aim of this study was to investigate the effect of vanadium on iodine uptake via vanadium-dependent iodoperoxidase (vHPO) activity in sweetcorn plants (Zea mays L. subsp. Mays Saccharata Group) "Złota Karłowa". The experiment was carried out with organic and inorganic iodine compounds, namely potassium iodide (KI), potassium iodate $\left(\mathrm{KIO}_{3}\right), 5$-iodosalicylic acid (5-ISA), and 2-iodobenzoic acid (2-IBeA), each used in a dose of $10 \mu \mathrm{M}$. These compounds were applied with and without vanadium in the form of ammonium methavanadate $\left(\mathrm{NH}_{4} \mathrm{VO}_{3}\right)$ at a dose of $0.1 \mu \mathrm{M}$. A double control was used, the first without iodine and vanadium and the second with vanadium but without iodine. Root length, root mass, and above-ground weight were significantly higher after iodine and vanadium compared to controls. Plants were collected at the five true leaf stage. vHPO activity level was much higher in the roots than in the leaves, but greater variation in the leaves was observed between treatments in terms of vHPO activity. Vanadium was shown to accumulate in the roots. The use of a relatively low dose of vanadium may have caused changes in the accumulation of this element in the aerial parts of the plant, leaves, and shoots. Fertilization with iodine and vanadium compounds decreased the accumulation of most minerals, macroelements, and microelements compared to controls. The obtained results of iodine accumulation in individual parts after applying iodine and vanadium fertilization testify to the stimulating effect of vanadium on iodine uptake and accumulation.
\end{abstract}

Keywords: iodine; vanadium; vanadium-dependent haloperoxidases; beneficial elements; stimulating effect; biofortification

\section{Introduction}

Around two billion people in the World suffer from health issues related to iodine deficiency in their diets [1,2]. The problem of insufficient amount of iodine in the diet concerns areas with a high 
degree of economic development and less economically developed countries. The recommended daily iodine intake through the diet ranges between 90-250 $\mu \mathrm{g}$. Iodine is responsible for proper functioning of the thyroid gland by synthesizing thyroxine (T4) and triiodothyronine (T3). Proper iodine concentrations in pregnant women protect against complications in the prenatal period (mental retardation), miscarriage, and infertility [3]. Multilateral organizations, such as WHO (World Health Organization), UNICEF (United Nations Children's Fund), ICCIDDs (International Council for Control of Iodine Deficiency Disorders) have been looking for effective and practical methods to introduce iodine into the human diet for over twenty years [4]. Table salt iodination has so far been the only cost-effective, common solution to supply this essential element to many households [4]. The process of biofortification of plants with iodine (as well as other elements, vitamins, and nutraceuticals) has become an alternative, effective, and cost-effective solution. Agro technical methods of enriching crops with iodine have become the subject of many scientific studies. Previous research on the effectiveness of enriching crop plants with iodine was conducted on several vegetable species, including lettuce $[5,6]$, spinach [7,8], tomato [9], cucumber [10], carrot, celery [11], and potato [12]. Research was also carried out on the efficiency of rice grain enrichment [13] of wheat, corn [14], and buckwheat [15]. In this experiment, an inorganic form of iodine $\mathrm{KI}_{\text {and }} \mathrm{KIO}_{3}$ was used for effective iodine biofortification. Halka et al. [16] used an organic form of iodine 5-iodosalicylic acid, 3,5-diiodosalicylic acid, 2-iodobenzoic acid, 4-iodobenzoic acid, and 2,3,5-triiodobenzoic acid to enrich a tomato plant with iodine. Sularz et al. [17] used 5-iodosalicylic acid and 3,5-diiodosalicylic acid for the biofortificaation of the lettuce. To achieve the most effective method of biofortification researchers conduct their experiments by applying iodine compounds to hydroponic culture systems [12], soil, [14] or by foliar spraying of plants [14,18].

The largest reservoir of iodine on Earth is seawater and the organisms living in this environment [19]. Brown algae species are the most efficient iodine accumulators, with an average content of $1 \%$ dry matter in Laminaria digitata [20]. Iodine uptake by seaweed L. digitata involves extracellular iodide oxidation via vanadium-dependent haloperoxidase (vHPO), among other enzymes [21]. In seaweed organisms, one function of iodine is its participation in antioxidant mechanisms that protect capsid and thallus surfaces against oxidative stress [22]. vHPO enzymes play central roles in both iodine uptake from seawater and in the synthesis of volatile hydrogen halides in marine algae $[23,24]$.

Vanadium occurs in several oxidation levels from -1 to +5 [25]. The result of rock leaching and natural volcanic eruption causes distribution of vanadium in the soil and air. It is released into the atmosphere during coal combustion processes and production of petroleum and is considered to be a fertilizer pollution used in agriculture $[25,26]$. In higher plants, vanadium still arouses the interest of scientists and researchers. The uptake and distribution of vanadium to above-ground plant parts occurs to a small extent. Roots are characterized by the highest degree of accumulation of vanadium $[27,28]$, with vanadium compounds inhibiting plant proton pumps in plasma membranes [21,29], which act as osmotic regulators in cells, i.e., by regulating intracellular $\mathrm{pH}$, response to stress conditions, and mineral deficiencies [30]. The application of high doses of vanadium may cause inhibition of macronutrient uptake and accumulation, resulting in deficiencies. Critically low Ca concentrations were observed in vanadium-treated beans [27], with excess vanadium potentially inhibiting phosphorus uptake, transport, and accumulation in aerial plant parts. Doses above $20 \mathrm{mg} \mathrm{V} \cdot \mathrm{kg}^{-1}$ soil resulted in these phenomena [31]. Studies conducted on mint by [32] did not show a radical decrease in Ca content in plants after vanadium fertilization.

Daily vanadium intake for humans ranges from 10 to $160 \mu \mathrm{g}$ [33-35], and is found in mushrooms, parsley, pepper [35-37], seafood, fresh fish [38], beer and wine, spinach, and fennel seeds [39]. Organic and inorganic vanadium compounds help to maintain glucose homeostasis (balance) in type 1 and type 2 diabetes mellitus due to gene expression of enzymes involved in glucose and lipid metabolism $[34,39,40]$. Vanadium also participates in bone and tooth metabolism and acts as an enzyme cofactor [41], further regulating the action of ( $\mathrm{Na}, \mathrm{K})$-ATPase, phosphotransferase, adenyl cycadadase, and protein kinase [41,42]. An important aspect is the dose and type of vanadium compound used [39]. Vanadium, like iodine, is involved in the metabolism of thyroid hormones [41,43]. 
Vanadium and iodine are known as beneficial elements for humans and animals, but also for higher plants. The benefits of iodine were supported by many studies on its functions and transformations in plants $[24,44,45]$. Classification of vanadium as a beneficial element for higher plants was based on research proving its participation in photosynthesis and the metabolism of nitrogen compounds [27,31]. Experiments carried out with legumes confirmed the effectiveness of vanadium and the possibility of replacing molybdenum with vanadium in nitrogen transformations and atmospheric nitrogen fixation [31] as part of the nitrogenase enzyme [46]. Vanadium is mainly found in algae, where it is part of the vanadium-dependent peroxidase enzyme responsible for iodine uptake and accumulation in marine algae tissues [20].

Previous studies conducted on enriching crop plants with iodine (biofortification) showed that vegetable leaves are characterized by higher accumulation and efficiency of iodine biofortification compared to the generative parts of plants [47]. Iodine is transported mainly by xylem [48,49]. This transport route could be an obstacle to the effective enrichment of this element in cereal grains. Mineral elements collected and accumulated in grain are transported by phloem [13], with research results showing that iodine transport through phloem is also possible [14,35]. Based on the many researches and searching for the most effective way of iodine biofortification we based on combination of iodine and vanadium as in L. digitata. Vanadium is as a metal ion which readily converts among oxidations states, has the potential to support catalytic processes through oxidation/reduction [50,51]. Mechanisms of iodine uptake and volatilization from cells by L. digitata mediated by vanadium-dependent iodoperoxidase [20].

The impact of vanadium on iodine uptake by higher plants, including crops, is not yet determined; therefore, the effect of simultaneous fertilization with iodine and vanadium on sweetcorn plants at an early developmental stage should be determined. The diet of several billion people in the world is based on cereals, including corn. Research carried out regarding iodine and vanadium uptake by sweetcorn plants may help in the development of the iodine enrichment (biofortification) process of this plant.

The aim of this study was to determine the effect of vanadium on the uptake and distribution of iodine in sweetcorn plants at an early vegetative stage of their growth. The hypothesis of this research was that vanadium would stimulate iodine uptake in sweetcorn plants, with the key role of this process played by the iodoperoxidase enzyme with vanadium acting as a cofactor. Next, vanadium and iodine fertilization could modify the uptake of macro- and microelements by plants.

\section{Materials and Methods}

\subsection{Plant Material and Cultivation}

The experiment was carried out with sweetcorn (Zea mays L. subsp. Mays Saccharata Group) "Złota Karłowa" and conducted by the Faculty of Biotechnology and Horticulture, University of Agriculture in Kraków. Seeds were sown into multipallets (propagation trays: $330 \times 520 \times 40 \mathrm{~mm}$ ) with cells $(32 \times 32 \times 40 \mathrm{~mm}$ in size) filled with sphagnum peat moss substrate (Hartmann) mixed with sand (1:1). Seedlings at the one true leaf phase were transplanted into $1.5 \mathrm{dm}^{3}$ pots and filled with peat substrate. Plants were cultivated in 4 replications of 3 plants (12 plants per combination of one plant per pot; see Figure 1). The total number of plants in the experiment was 120 . The plants were grown in a phytotron. During cultivation, the plants were illuminated with a $600 \mathrm{~W}$ high-pressure sodium lamp (photosynthetic photon flux density /PPFD/) reaching the plants was approximately $\left.200 \mu \mathrm{mol} \mathrm{m}{ }^{-2} \mathrm{~s}^{-1}\right)$, maintaining a photoperiod of $10 \mathrm{~h}$ of light: $14 \mathrm{~h}$ of darkness. The air temperature was $25^{\circ} \mathrm{C}$ during the day and $20^{\circ} \mathrm{C}$ at night. The experiment was conducted twice. Organization of the pots in the phytotron was randomized. 

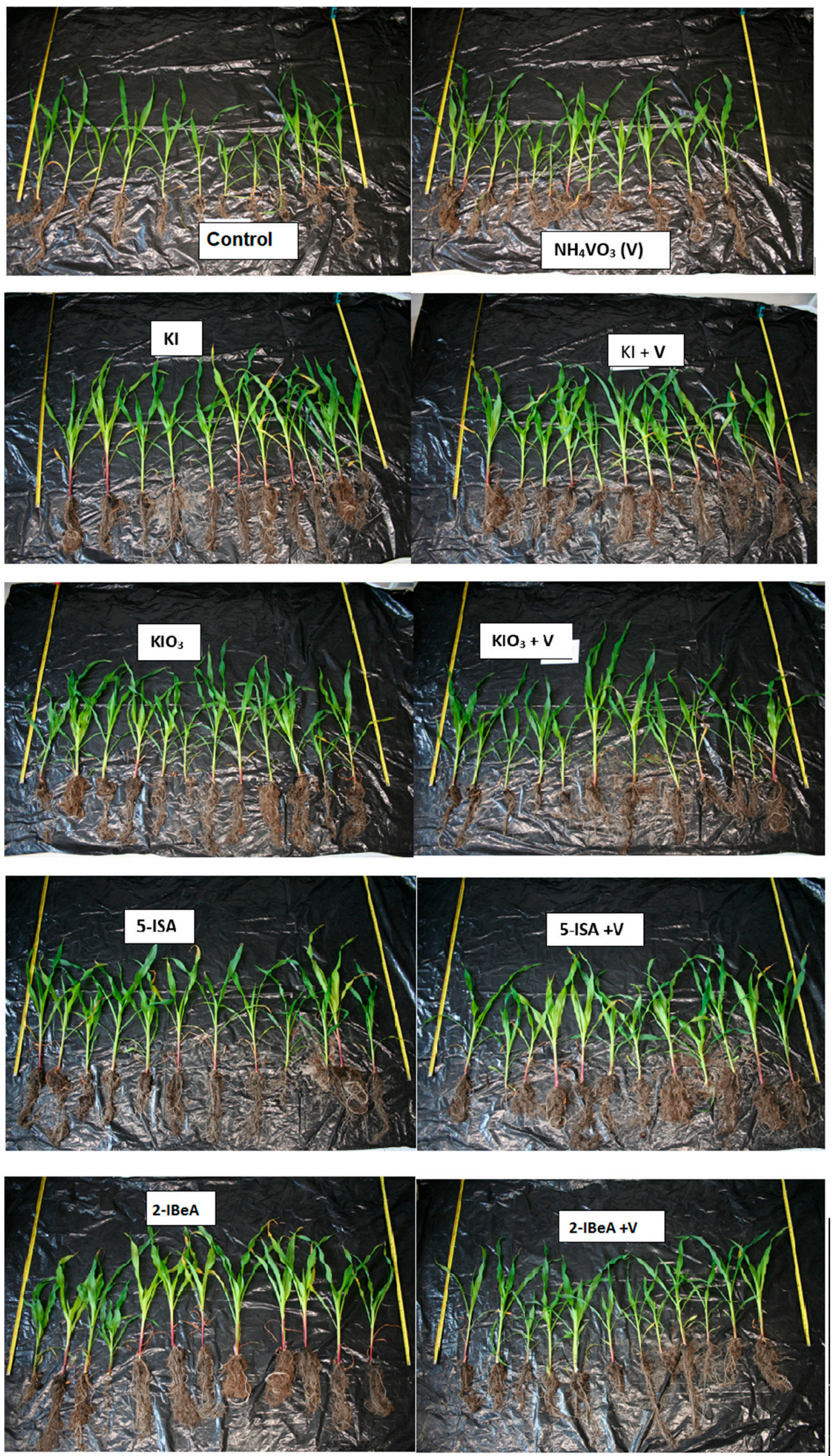

Figure 1. Sweet corn plants after harvest in $\mathrm{BBCH} 15$ the developmental phase. 
The study plan included ten combinations of plant treatment with various iodine compounds, including potassium iodide (KI), potassium iodate $\left(\mathrm{KIO}_{3}\right)$, 5-iodosalicylic acid (5-ISA), and 2-iodobenzoic acid (2-IBeA) and vanadium in the form of ammonium methanadate $\left(\mathrm{NH}_{4} \mathrm{VO}_{3}\right)$ (Table 1). Chosen dose of vanadium and iodine, $10 \mu \mathrm{M}$ iodine and $0.1 \mu \mathrm{M}$ vanadium was based on preliminary research, which was done to prepare a two-cycle experiment in phytotron. The main aim was to adjust a safe dose of vanadium and iodine for plants.

Table 1. Doses of applied compounds $(\mu \mathrm{M})$.

\begin{tabular}{ccc}
\hline & \multicolumn{2}{c}{ Dose of Applied Compounds $(\mu \mathrm{M})$} \\
\hline Treatments & Iodine & Vanadium \\
\hline Control & - & - \\
$\mathrm{V}$ & - & $0.1 \mu \mathrm{M}$ \\
$\mathrm{KI}$ & $10 \mu \mathrm{M}$ & - \\
$\mathrm{KI}+\mathrm{V}$ & $10 \mu \mathrm{M}$ & $0.1 \mu \mathrm{M}$ \\
$\mathrm{KIO}_{3}$ & $10 \mu \mathrm{M}$ & - \\
$\mathrm{KIO}_{3}+\mathrm{V}$ & $10 \mu \mathrm{M}$ & $0.1 \mu \mathrm{M}$ \\
5-ISA & $10 \mu \mathrm{M}$ & - \\
5-ISA+V & $10 \mu \mathrm{M}$ & $0.1 \mu \mathrm{M}$ \\
2-IBeA & $10 \mu \mathrm{M}$ & - \\
2-IBeA $+\mathrm{V}$ & $10 \mu \mathrm{M}$ & $0.1 \mu \mathrm{M}$ \\
\hline
\end{tabular}

Compounds of iodine and vanadium were applied four times by fertigation. The fertigation process started on day 7 post-transplantation of the plants into the pots. The time between applications was 3 days (two true leaf stage). A single application dose for one pot (one plant) involved adding $100 \mathrm{~mL}$ of each tested solution. The plants were harvested 4 weeks after sowing (five true leaf stage-in BBCH 15 the developmental phase). The experiment was conducted twice, with biometric measurements made during the harvest. Root length and weight as well as height were determined alongside the mass of aerial plant parts. Roots and aerial parts (leaves and stems) were washed in tap water and then distilled water. The second part of preparation for chemical analysis involved chopping these parts up into fragments of about $1-2 \mathrm{~cm}$.

Calculation of iodine or vanadium uptake by plants was performed according to the formula (average of iodine or vanadium concentration $\mathrm{mg} \cdot \mathrm{kg}^{-1} \mathrm{~d} . \mathrm{w} . \times$ total dry weight content in each plant parts this is leaves, roots or stems separately: $1000=$ results in $\mu \mathrm{g}$ of $\mathrm{I}$ or $\mathrm{V} \cdot$ part of plant ${ }^{-1}$ ).

\subsection{Analysis of Fresh Plant Material Sample}

The analysis of the total activity of vanadium-dependent haloperoxidases enzymes (vHPO) was determined based on the procedure described by Smolen et al. [52].

\subsection{Analysis of Dry Samples of Roots, Stems, and Leaves}

Fresh samples of roots, shoots, and leaves were dried at $70{ }^{\circ} \mathrm{C}(48 \mathrm{~h})$ in a laboratory dryer with forced air circulation. Dried samples of leaves, roots, and stems were ground in a laboratory mill and stored in a plastic bag until the analysis of iodine, vanadium, macroelement, and microelement contents was carried out.

To determine iodine content, the PN-EN 15111-2008 method was used with the modifications described by Smoleń et al. [53].

The concentrations of $\mathrm{V}, \mathrm{P}, \mathrm{K}, \mathrm{Mg}, \mathrm{Ca}, \mathrm{S}, \mathrm{B}, \mathrm{Cu}, \mathrm{Fe}, \mathrm{Mn}, \mathrm{Mo}$, and $\mathrm{Zn}$ were determined using the ICP-OES spectrophotometer after microwave digestion in $65 \%$ super pure $\mathrm{HNO}_{3}$. Plant samples of $0.5 \mathrm{~g}$ of dry material were placed in $55 \mathrm{~mL}$ TFM modified polytetrafluoroethylene (PTFE) vessels and digested in $10 \mathrm{~mL}$ of $65 \% \mathrm{HNO}_{3}$ using a CEM MARS-5 Xpress microwave digestion system [54]. 


\subsection{Data Analysis}

All data were statistically verified using the one-way analysis of variance (ANOVA) module of the Statistica 12 PL program at a significance level of $\alpha=0.05$. The significance of differences between the means was estimated using Tukey's test at the assumed significance level of $\alpha=0.05$.

\section{Results}

\subsection{Plant Growth}

Tested treatments of iodine and vanadium fertilization compared to the control (without iodine and vanadium) statistically increased root length and weight, except for root weight after application of $\mathrm{V}$ and $\mathrm{KIO}_{3}$ (Table 2). In the aerial parts of the plants, height was significantly greater than the control after fertilization with $\mathrm{KI}, \mathrm{KI}+\mathrm{V}$, and $\mathrm{KIO}_{3}$, and significantly less than the control after application of 2-IBeA+V. Limiting plant growth after 2-IBeA+V demonstrated no negative effect on aerial plant parts, which was similar to what was observed in the control. Significantly higher aerial plant parts were noted after the application of $\mathrm{KI}, \mathrm{KI}+\mathrm{V}, \mathrm{KIO}_{3}, \mathrm{KIO}_{3}+\mathrm{V}$, 5-ISA, 5-ISA+V, and 2-IBeA compared to the control. The application of $\mathrm{KIO}_{3}$ resulted in a statistically increased shoot/root ratio compared to the application of 5ISA, 5ISA+V, and 2IBeA. Fertilization vanadium and iodine did not significantly affect shoot/root ratio compared to the control.

Table 2. Root length and weight and of the aerial part's height and weight of sweetcorn plants at an early stage of development.

\begin{tabular}{|c|c|c|c|c|c|}
\hline Treatment & $\begin{array}{l}\text { Root Length } \\
\text { (cm) }\end{array}$ & $\begin{array}{l}\text { Plant Height } \\
\text { (Aerial Part of } \\
\text { the Plant) }(\mathrm{cm})\end{array}$ & Root Weight (g) & $\begin{array}{l}\text { Plant Weight } \\
\text { (Aerial Part of } \\
\text { the Plant) (g) }\end{array}$ & $\begin{array}{c}\text { Shoot/Root } \\
\text { Ratio }\end{array}$ \\
\hline Control & $12.08 \pm 1.39^{a}$ & $58.17 \pm 0.64^{b, c}$ & $5.11 \pm 0.71^{a}$ & $26.82 \pm 2.21^{\mathrm{a}}$ & $5.1 \pm 0.61^{a, b, c}$ \\
\hline $\mathrm{V}$ & $16.83 \pm 1.75^{b}$ & $58.17 \pm 1.37^{b, c}$ & $7.17 \pm 1.15^{\mathrm{a}, \mathrm{b}}$ & $34.43 \pm 4.42^{\mathrm{a}, \mathrm{b}}$ & $5.2 \pm 0.88^{\mathrm{a}, \mathrm{b}, \mathrm{c}}$ \\
\hline KI & $22.50 \pm 2.10^{c, d}$ & $61.50 \pm 1.95^{\mathrm{d}}$ & $14.37 \pm 3.21^{\mathrm{c}, \mathrm{d}}$ & $54.06 \pm 5.98^{c, d}$ & $5.1 \pm 1.20^{\mathrm{a}, \mathrm{b}, \mathrm{c}}$ \\
\hline $\mathrm{KI}+\mathrm{V}$ & $16.46 \pm 2.53^{b}$ & $65.50 \pm 1.00^{\mathrm{e}}$ & $14.52 \pm 3.43^{c, d}$ & $62.27 \pm 5.56^{\mathrm{d}}$ & $6.0 \pm 1.38^{b, c}$ \\
\hline $\mathrm{KIO}_{3}$ & $17.58 \pm 2.94^{b}$ & $62.33 \pm 1.36^{\mathrm{d}}$ & $10.07 \pm 2.33^{a, b, c}$ & $50.65 \pm 6.51^{c, d}$ & $7.0 \pm 1.42^{c}$ \\
\hline $\mathrm{KIO}_{3}+\mathrm{V}$ & $20.83 \pm 1.71^{c, d}$ & $57.92 \pm 2.29^{b}$ & $8.52 \pm 1.03^{a, b, c}$ & $43.48 \pm 5.69^{b, c}$ & $5.0 \pm 0.50^{a, b, c}$ \\
\hline 5-ISA & $20.33 \pm 1.92^{c}$ & $60.96 \pm 2.19^{c, d}$ & $12.61 \pm 1.50^{b, c, d}$ & $40.14 \pm 2.71^{b, c}$ & $3.2 \pm 0.32 \mathrm{a}, \mathrm{b}$ \\
\hline $5-\mathrm{ISA}+\mathrm{V}$ & $26.83 \pm 0.37^{e}$ & $59.50 \pm 1.98^{b, c, d}$ & $18.95 \pm 2.13^{\mathrm{d}, \mathrm{e}}$ & $49.95 \pm 6.04^{\mathrm{c}, \mathrm{d}}$ & $2.7 \pm 0.23^{a}$ \\
\hline 2-IBeA & $23.00 \pm 1.49^{\mathrm{d}}$ & $57.38 \pm 3.30^{b}$ & $23.02 \pm 5.36^{\mathrm{e}}$ & $44.45 \pm 8.08^{b, c}$ & $2.5 \pm 0.36^{\mathrm{a}}$ \\
\hline 2-IBeA+V & $21.33 \pm 2.18^{\mathrm{c}, \mathrm{d}}$ & $49.00 \pm 3.43^{\mathrm{a}}$ & $9.24 \pm 1.48^{\mathrm{a}, \mathrm{b}, \mathrm{c}}$ & $30.69 \pm 3.48^{\mathrm{a}, \mathrm{b}}$ & $4.0 \pm 0.94^{\mathrm{a}, \mathrm{b}, \mathrm{c}}$ \\
\hline
\end{tabular}

Identical letters in superscript indicate the means are not significantly different at $P<0.05$; different letters indicate statistically significant differences at $P \leq 0.05(n=8)$. The developmental phase of maize: BBCH 15.

Plants after application of 5-ISA+V demonstrated the most developed root system, with roots twice as long as those observed in the control. Roots of plants treated with 5-ISA+V resulted in a mass three times greater than the control (Table 2). However, the largest root mass, more than four times greater than the control, was found after the application of 2-IBeA. Nevertheless, the greatest mass and highest aerial plant parts were obtained after fertilization with $\mathrm{KI}+\mathrm{V}$ maize (Table 2).

\subsection{Uptake and Accumulation of Iodine in Maize Plants}

Fertigation of organic and inorganic iodine compounds significantly increased the iodine contents of roots, shoots, and leaves of maize plants compared to the control (Figure 2A-C). Vanadium fertilization combined with organic and inorganic iodine compounds showed a statistically significant increase in the iodine contents of the roots, shoots, and leaves in comparison with $\mathrm{KI}, \mathrm{KIO}_{3}, 5-\mathrm{ISA}$, and 2-IBeA application without vanadium (Figure 2A-C). Fertilization of vanadium (without iodine) compared to the control showed a significant increase in corn root, shoot, and leaf iodine contents. 

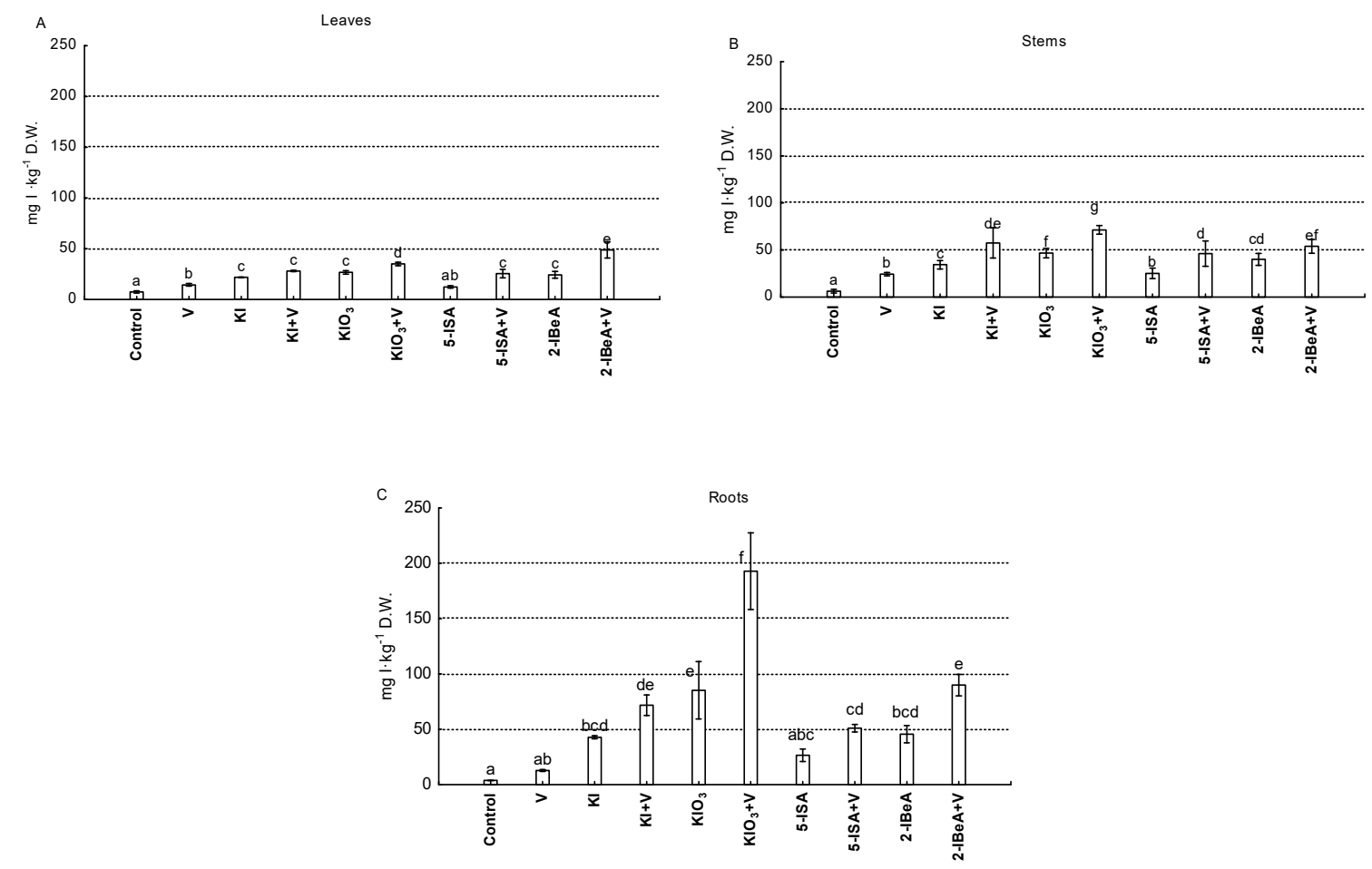

Figure 2. Iodine contents in leaves $(\mathbf{A})$, shoots $(\mathbf{B})$, and roots $(\mathbf{C})$ of maize. Identical letters in superscript indicate means are not significantly different at $P<0.05$; different letters indicate statistically significant differences at $P \leq 0.05(n=8)$. The developmental phase of maize: $\mathrm{BBCH} 15$.

Regardless of the type of iodine compound fertilization, the highest iodine content was observed in the roots, followed by the shoots and, lastly, the leaves (Figure 2A-C). The highest contents of iodine were found after $\mathrm{KIO}_{3}+\mathrm{V}$ fertilization in roots and shoots, and in leaves after the 2-IBeA+V application.

Iodine uptake by roots, shoots, and leaves (Figure $3 \mathrm{~A}-\mathrm{C}$ ) was different from the results determined by iodine content (Figure 2), probably because the iodine uptake was calculated based on yield, whereas iodine contents in the roots, shoots, and leaves was calculated using dry matter content data (Supplementary Materials Table S1). Plant fertilization with iodine and vanadium compounds (compared to without vanadium) caused a significant increase in iodine uptake by the roots, shoots, and leaves of plants fertilized with $\mathrm{KI}+\mathrm{V}$ versus $\mathrm{KI}$ (Figure 3A-C). The results show the use of $\mathrm{KIO}_{3}+\mathrm{V}$, 5-ISA+V, and 2-IBeA+V versus $\mathrm{KIO}_{3}$ fertilization, with 5-ISA and 2-IBeA demonstrating no effect on iodine uptake by roots, shoots, or leaves.

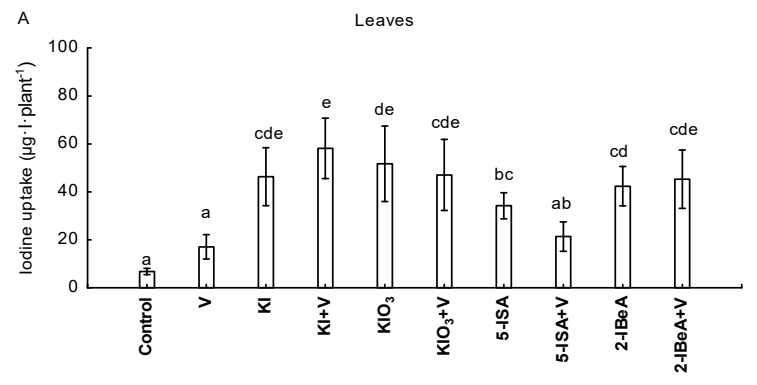

Figure 3. Cont. 

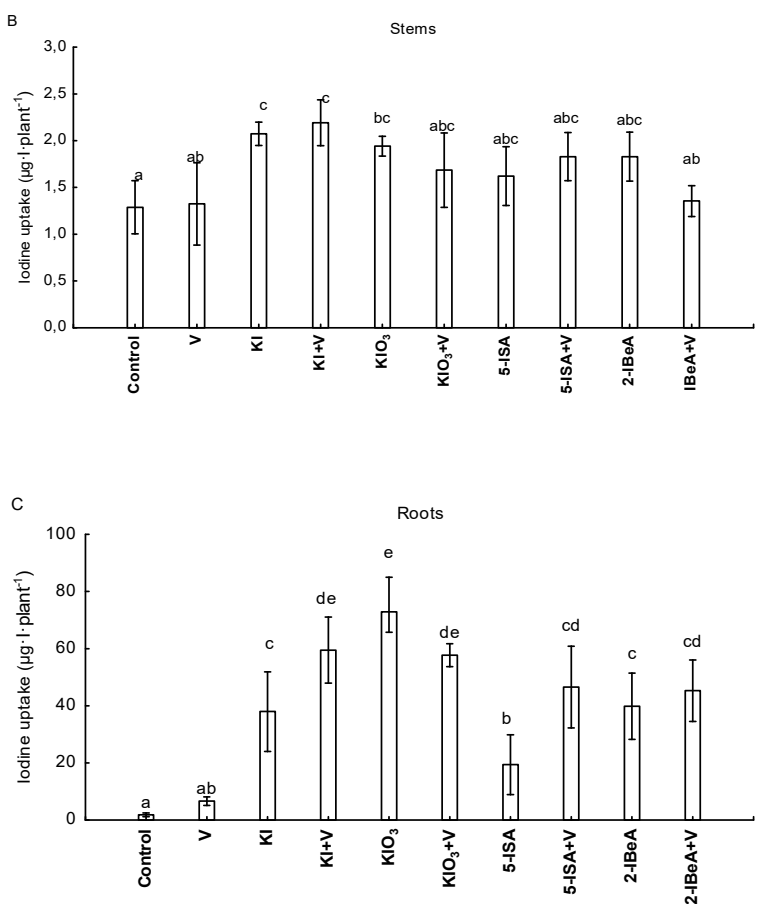

Figure 3. Iodine uptake by leaves (A), shoots (B), and roots (C) of maize. Identical letters in superscript indicate means are not significantly different at $P<0.05$; different letters indicate statistically significant differences at $P \leq 0.05(n=8)$. The developmental phase of maize: $\mathrm{BBCH} 15$.

\subsection{Activity of vHPO and Content and Uptake of Vanadium by Maize Plants}

vHPO activity levels were determined to be higher in the roots than in the leaves of plants (Figure 4A,B). A significant variation between areas in terms of vHPO activity in plants was observed alongside greater variation in the leaves than in the roots of sweetcorn plants.
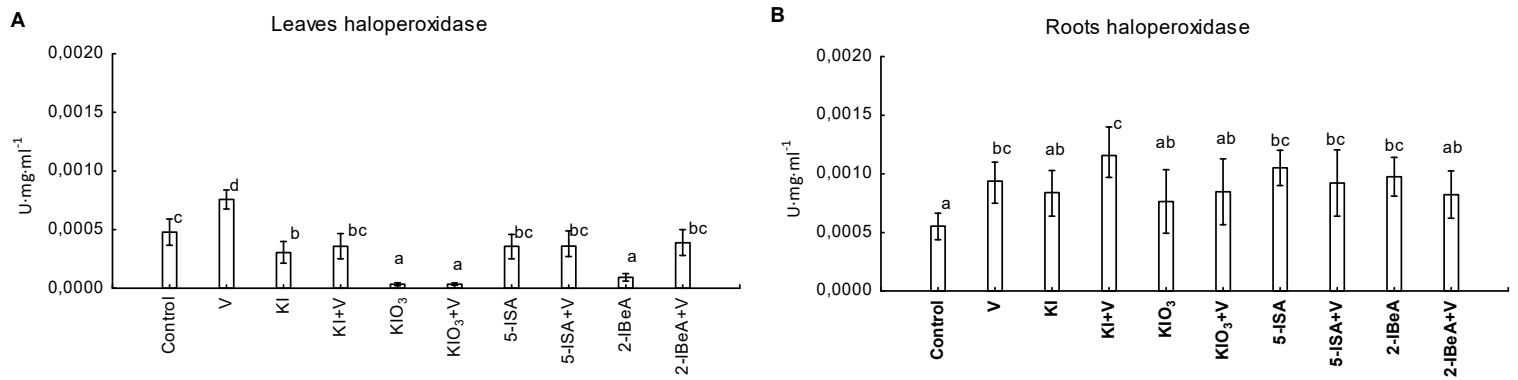

Figure 4. Activity of vanadium-dependent iodoperoxidase (vHPO) in maize leaves (A) and roots (B). Identical letters in superscript indicate means are not significantly different at $P<0.05$; different letters indicate statistically significant differences at $P \leq 0.05(n=8)$. The developmental phase of maize: BBCH 15.

Vanadium application alone (without iodine) resulted in a significant increase in vHPO activity relative to the control in the leaves. Fertigation of $\mathrm{KIO}_{3}, \mathrm{KIO}_{3}+\mathrm{V}$, and 2-IBeA caused a five-fold reduction in vHPO activity in sweetcorn leaves. Plants fertilized with KI alone (without vanadium) also reduced vHPO activity in the leaves. However, the highest vHPO activity was observed in the roots after $\mathrm{KI}+\mathrm{V}$ fertilization, with statistically greater vHPO activity found in roots after application of $\mathrm{V}$, 5-ISA, 5-ISA+V, and 2-IBeA+V compared to the control (Figure 4B).

Vanadium contents in the roots, shoots, and leaves were comparable to each analyzed part of the plants (Figure 5A-C). In comparison to the control, vanadium contents increased in maize roots after fertigation of vanadium alone, as well as when combined with all iodine compounds. Comparing 
vanadium fertilization versus control or the iodine compound applied to the roots, a significant increase in vanadium content in the roots in the two tested treatments was observed, i.e., $\mathrm{V}$ versus control and $\mathrm{KIO}_{3}+\mathrm{V}$ versus $\mathrm{KIO}_{3}$. The highest accumulation of vanadium was observed in the roots after fertilization of ammonium metavanadate. It is worth highlighting that the vanadium contents were lower in the shoots and leaves than in the control for all tested treatments except for 2-IBeA+V, with the leaves showing significantly increased V accumulation (Figure 5A-B).
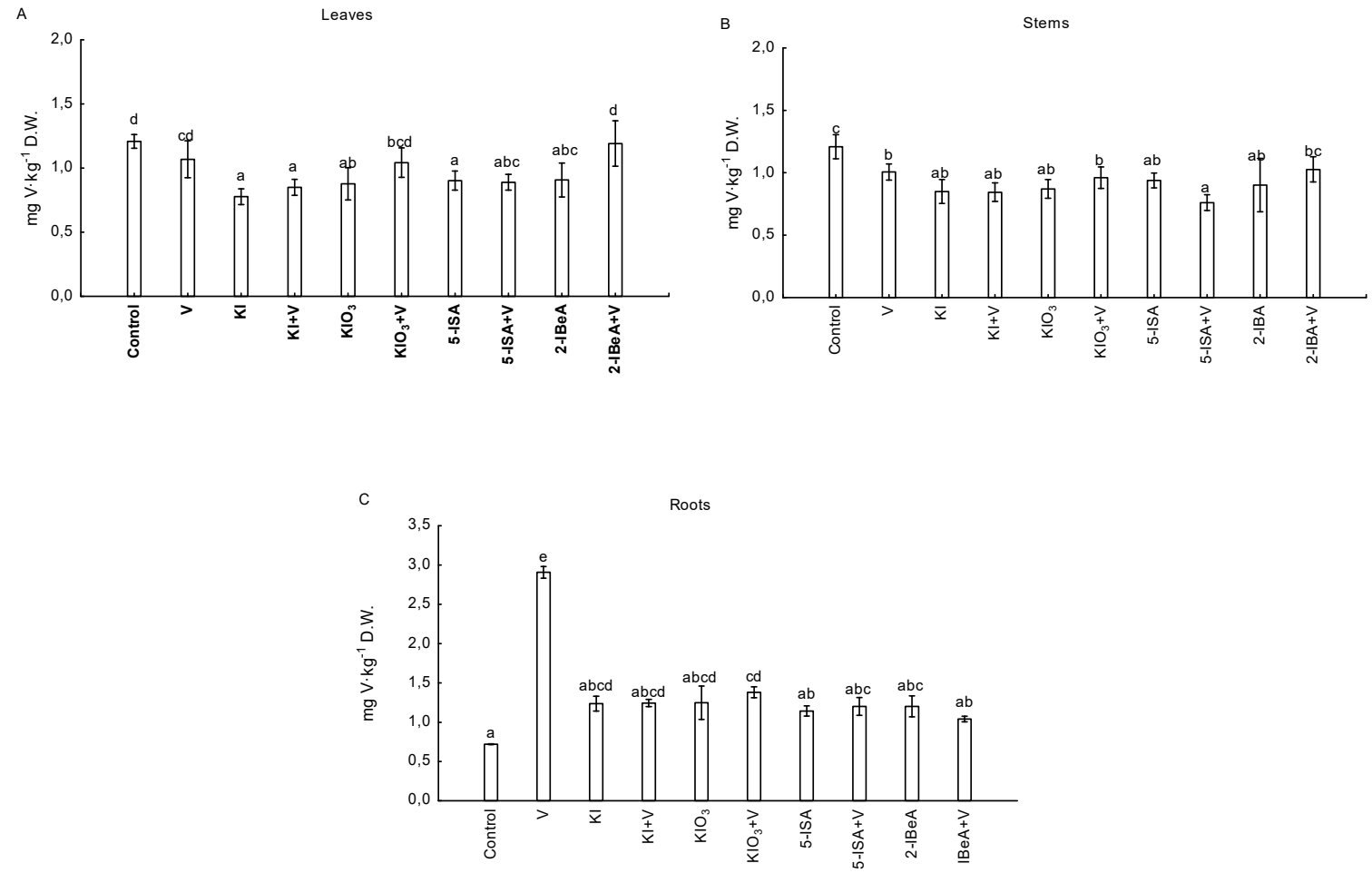

Figure 5. Vanadium contents in leaves (A), shoots (B), and roots (C) in maize. Identical letters in superscript indicate means are not significantly different at $P<0.05$; different letters indicate statistically significant differences at $P \leq 0.05(n=8)$. The developmental phase of maize: BBCH 15.

The results presented above show an inefficient effect of $\mathrm{NH}_{4} \mathrm{VO}_{3}$ fertilization based on low vanadium accumulation in plant (maize) parts, which could be an artifact of too low a dose of $\mathrm{NH}_{4} \mathrm{VO}_{3}$. This dose did not cause a spectacular increase in vanadium content in maize, particularly in the leaves and shoots. Therefore, it is likely that the used dose of vanadium was the level of maize physiological vanadium demand. Calculations of V-uptake levels by stems and leaves (Figure 6A-C) showed a close synergistic relationship between vanadium and iodine in maize plants. All iodine compounds used without vanadium applied to the soil resulted in an increase in V-uptake by roots, stems, and leaves compared to the control. Therefore, combined fertilization with iodine and vanadium (compared to KI, $\mathrm{KIO}_{3}, 5-\mathrm{ISA}$, and 2-IBeA without vanadium) did not increase the level of V-uptake by roots, stems, or leaves. The result demonstrating the superior role of iodine over vanadium in the uptake process by corn plants. 

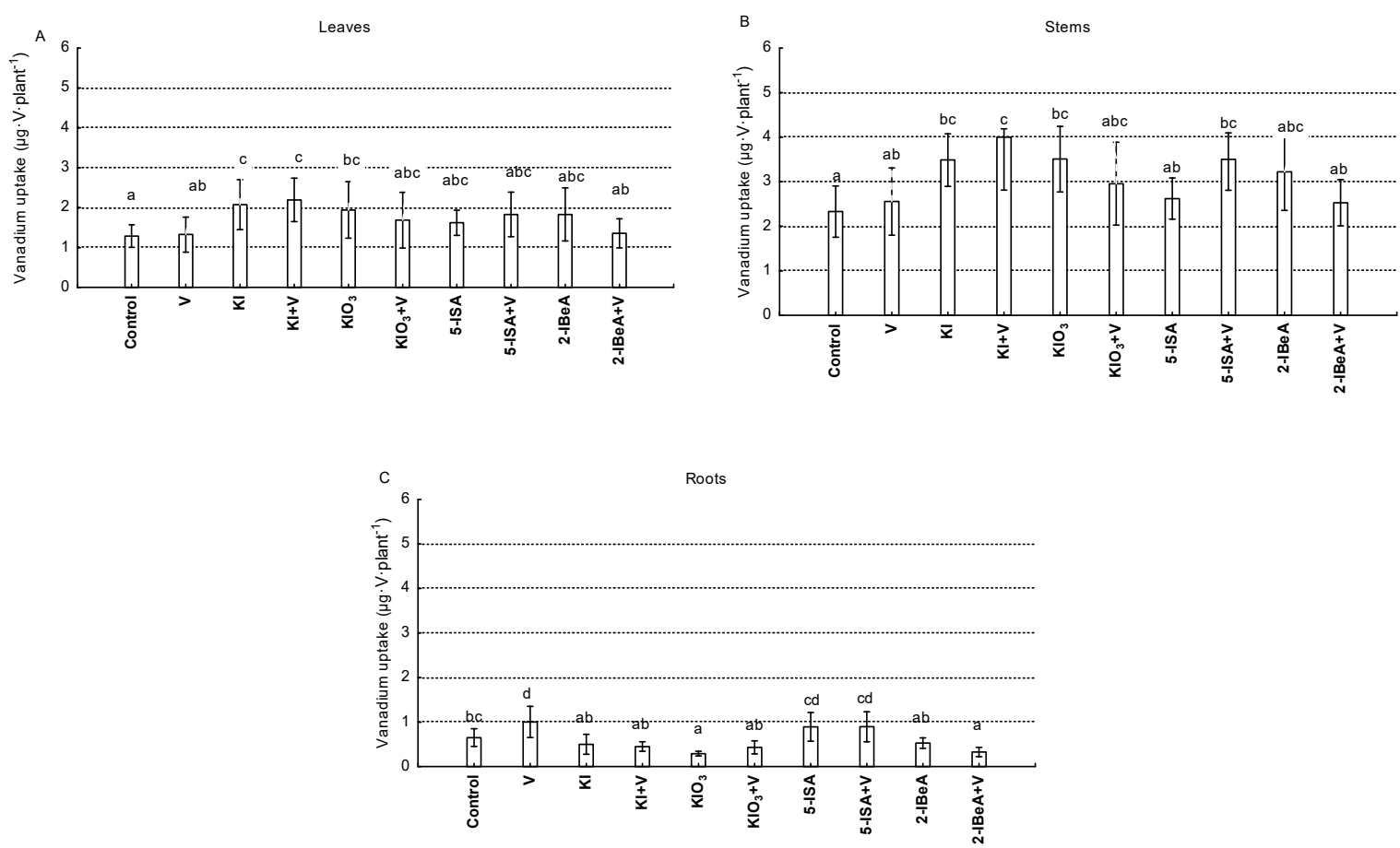

Figure 6. Vanadium uptake by leaves (A), shoots (B), and roots (C) in maize. Identical letters in superscript indicate means are not significantly different at $P<0.05$; different letters indicate statistically significant differences at $P \leq 0.05(n=8)$. The developmental phase of maize: BBCH 15.

\subsection{Contents of Macroelements and Microelements in Maize Plants}

Application of iodine and vanadium treatment showed a significant effect on the contents of all microelements and macroelements in the roots, shoots, and leaves of maize (Tables 3 and 4).

Table 3. Contents of macroelements (Ca, K, Mg, P, and S) in leaves, shoots, and roots of "Złota Karłowa" sweetcorn at an early stage of development.

\begin{tabular}{|c|c|c|c|c|c|}
\hline \multicolumn{6}{|c|}{ Leaves (g kg-1 d.w) } \\
\hline Treatment & $\mathrm{Ca}$ & $\mathbf{K}$ & $\mathrm{Mg}$ & $\mathbf{P}$ & $S$ \\
\hline Control & $1.13 \pm 0.025^{\mathrm{d}}$ & $4.68 \pm 0.133^{f}$ & $0.31 \pm 0.003^{\mathrm{d}}$ & $0.68 \pm 0.046^{\mathrm{e}}$ & $0.24 \pm 0.005^{\mathrm{a}}$ \\
\hline $\mathrm{V}$ & $1.06 \pm 0.026^{\mathrm{c}, \mathrm{d}}$ & $4.41 \pm 0.143^{\mathrm{e}}$ & $0.27 \pm 0.002^{c}$ & $0.58 \pm 0.031^{\mathrm{d}}$ & $0.25 \pm 0.002^{a, b, c}$ \\
\hline KI & $0.79 \pm 0.010^{\mathrm{a}}$ & $4.02 \pm 0.140^{\mathrm{c}, \mathrm{d}}$ & $0.21 \pm 0.004^{\mathrm{a}}$ & $0.47 \pm 0.015^{b}$ & $0.25 \pm 0.009^{a, b}$ \\
\hline $\mathrm{KI}+\mathrm{V}$ & $0.92 \pm 0.006^{b}$ & $3.79 \pm 0.087^{b, c}$ & $0.22 \pm 0.004^{\mathrm{a}, \mathrm{b}}$ & $0.43 \pm 0.018^{\mathrm{a}, \mathrm{b}}$ & $0.26 \pm 0.006^{b, c}$ \\
\hline $\mathrm{KIO}_{3}$ & $0.90 \pm 0.016^{b}$ & $4.27 \pm 0.160^{\mathrm{d}, \mathrm{e}}$ & $0.24 \pm 0.008^{b}$ & $0.51 \pm 0.028^{c}$ & $0.25 \pm 0.005^{a, b, c}$ \\
\hline $\mathrm{KIO}_{3}+\mathrm{V}$ & $1.12 \pm 0.035^{\mathrm{d}}$ & $4.22 \pm 0.128^{\mathrm{d}, \mathrm{e}}$ & $0.30 \pm 0.004^{\mathrm{d}}$ & $0.59 \pm 0.028^{d}$ & $0.26 \pm 0.005^{b, c}$ \\
\hline 5-ISA & $0.93 \pm 0.051^{b}$ & $4.13 \pm 0.041^{\mathrm{d}}$ & $0.23 \pm 0.006^{\mathrm{a}, \mathrm{b}}$ & $0.52 \pm 0.002^{c}$ & $0.26 \pm 0.015^{c}$ \\
\hline $5-\mathrm{ISA}+\mathrm{V}$ & $0.92 \pm 0.041^{b}$ & $3.61 \pm 0.028^{\mathrm{a}, \mathrm{b}}$ & $0.24 \pm 0.004^{b}$ & $0.43 \pm 0.002^{\mathrm{a}}$ & $0.26 \pm 0.013^{b, c}$ \\
\hline 2-IBeA & $0.98 \pm 0.073^{b, c}$ & $3.49 \pm 0.141^{\mathrm{a}}$ & $0.22 \pm 0.011^{\mathrm{a}, \mathrm{b}}$ & $0.45 \pm 0.014^{\mathrm{a}, \mathrm{b}}$ & $0.26 \pm 0.023 b, c$ \\
\hline 2-IBeA+V & $1.23 \pm 0.076^{\mathrm{e}}$ & $3.85 \pm 0.190^{b, c}$ & $0.26 \pm 0.014^{c}$ & $0.56 \pm 0.027^{\mathrm{d}}$ & $0.26 \pm 0.013^{b, c}$ \\
\hline \multicolumn{6}{|c|}{ Stems $\left(\mathrm{g} \mathrm{kg}^{-1}\right.$ d.w $)$} \\
\hline Control & $0.95 \pm 0.031^{f}$ & $8.15 \pm 0.282^{d}$ & $0.41 \pm 0.013^{\mathrm{e}}$ & $0.68 \pm 0.008^{\mathrm{e}}$ & $0.19 \pm 0.011^{\mathrm{a}, \mathrm{b}}$ \\
\hline $\mathrm{V}$ & $0.84 \pm 0.021^{\mathrm{e}}$ & $8.33 \pm 0.491^{\mathrm{d}}$ & $0.37 \pm 0.006^{\mathrm{d}}$ & $0.64 \pm 0.017^{\mathrm{d}, \mathrm{e}}$ & $0.21 \pm 0.013^{c}$ \\
\hline KI & $0.70 \pm 0.029^{a}$ & $6.61 \pm 0.643^{a, b, c}$ & $0.29 \pm 0.026^{\mathrm{a}, \mathrm{b}}$ & $0.49 \pm 0.011^{\mathrm{a}, \mathrm{b}}$ & $0.19 \pm 0.01^{\mathrm{a}}$ \\
\hline $\mathrm{KI}+\mathrm{V}$ & $0.71 \pm 0.013^{\mathrm{a}, \mathrm{b}}$ & $5.63 \pm 0.802^{\mathrm{a}}$ & $0.26 \pm 0.022^{a}$ & $0.42 \pm 0.044^{\mathrm{a}}$ & $0.19 \pm 0.02^{\mathrm{a}}$ \\
\hline $\mathrm{KIO}_{3}$ & $0.75 \pm 0.028^{c, d}$ & $7.37 \pm 0.703^{b, c, d}$ & $0.33 \pm 0.031^{c, d}$ & $0.54 \pm 0.01^{b, c}$ & $0.20 \pm 0.01^{\mathrm{a}, \mathrm{b}, \mathrm{c}}$ \\
\hline $\mathrm{KIO}_{3}+\mathrm{V}$ & $0.83 \pm 0.041^{\mathrm{e}}$ & $7.87 \pm 0.66^{\mathrm{d}}$ & $0.37 \pm 0.024^{d}$ & $0.62 \pm 0.007^{\mathrm{d}, \mathrm{e}}$ & $0.19 \pm 0.003^{a}$ \\
\hline 5-ISA & $0.78 \pm 0.017^{\mathrm{d}}$ & $7.44 \pm 0.46^{\mathrm{c}, \mathrm{d}}$ & $0.31 \pm 0.013^{b, c}$ & $0.58 \pm 0.013^{c, d}$ & $0.20 \pm 0.0144^{a, b, c}$ \\
\hline $5-\mathrm{ISA}+\mathrm{V}$ & $0.73 \pm 0.024^{\mathrm{a}, \mathrm{b}, \mathrm{c}}$ & $6.25 \pm 0.492^{\mathrm{a}, \mathrm{b}}$ & $0.31 \pm 0.014^{b, c}$ & $0.49 \pm 0.01^{\mathrm{a}, \mathrm{b}}$ & $0.19 \pm 0.012^{a, b, c}$ \\
\hline
\end{tabular}


Table 3. Cont.

\begin{tabular}{|c|c|c|c|c|c|}
\hline \multicolumn{6}{|c|}{ Leaves $\left(\mathrm{g} \mathrm{kg}^{-1}\right.$ d.w) } \\
\hline Treatment & $\mathrm{Ca}$ & $\mathbf{K}$ & Mg & $\mathbf{P}$ & S \\
\hline 2-IBeA & $0.74 \pm 0.049^{b, c}$ & $5.94 \pm 0.596^{\mathrm{a}}$ & $0.29 \pm 0.021^{\mathrm{a}, \mathrm{b}}$ & $0.51 \pm 0.004^{b, c}$ & $0.19 \pm 0.021^{\mathrm{a}}$ \\
\hline 2-IBeA+V & $0.86 \pm 0.010^{\mathrm{e}}$ & $7.33 \pm 0.443^{b, c, d}$ & $0.35 \pm 0.022 \mathrm{~d}$ & $0.67 \pm 0.017^{\mathrm{e}}$ & $0.21 \pm 0.01 b, c$ \\
\hline \multicolumn{6}{|c|}{ Roots (mg kg ${ }^{-1}$ d.w) } \\
\hline Control & $0.94 \pm 0.004^{a, b, c}$ & $2.95 \pm 0.019^{d}$ & $0.20 \pm 0.001^{b, c}$ & $0.23 \pm 0.001^{f}$ & $0.48 \pm 0.003^{c, d}$ \\
\hline V & $0.87 \pm 0.006^{\mathrm{a}}$ & $2.89 \pm 0.031^{\mathrm{d}}$ & $0.17 \pm 0.002^{\mathrm{a}}$ & $0.18 \pm 0.002^{\mathrm{d}}$ & $0.46 \pm 0.003^{b, c, d}$ \\
\hline KI & $1.04 \pm 0.002^{\mathrm{d}}$ & $2.57 \pm 0.003^{b}$ & $0.22 \pm 0.001^{\mathrm{c}}$ & $0.18 \pm 0.001^{\mathrm{d}}$ & $0.45 \pm 0.002^{b, c}$ \\
\hline $\mathrm{KI}+\mathrm{V}$ & $0.99 \pm 0.005^{b, c, d}$ & $2.37 \pm 0.007^{a, b}$ & $0.22 \pm 0.001^{c}$ & $0.15 \pm 0.001^{b}$ & $0.38 \pm 0.002^{\mathrm{a}}$ \\
\hline $\mathrm{KIO}_{3}$ & $1.00 \pm 0.033^{b, c, d}$ & $2.59 \pm 0.084^{b, c}$ & $0.20 \pm 0.008^{c}$ & $0.16 \pm 0.005^{c}$ & $0.46 \pm 0.015^{b, c, d}$ \\
\hline $\mathrm{KIO}_{3}+\mathrm{V}$ & $0.97 \pm 0.002^{b, c, d}$ & $2.82 \pm 0.001^{c, d}$ & $0.18 \pm 0.001^{\mathrm{a}, \mathrm{b}}$ & $0.22 \pm 0.001^{\mathrm{e}}$ & $0.45 \pm 0.002^{b, c, d}$ \\
\hline 5-ISA & $0.84 \pm 0.006^{\mathrm{a}}$ & $2.91 \pm 0.013^{\mathrm{d}}$ & $0.18 \pm 0.001^{\mathrm{a}, \mathrm{b}}$ & $0.20 \pm 0.002^{d}$ & $0.41 \pm 0.003^{\mathrm{a}, \mathrm{b}}$ \\
\hline $5-\mathrm{ISA}+\mathrm{V}$ & $0.90 \pm 0.004^{\mathrm{a}, \mathrm{b}}$ & $2.14 \pm 0.010^{a}$ & $0.20 \pm 0.001^{b, c}$ & $0.14 \pm 0.000^{\mathrm{a}}$ & $0.38 \pm 0.002^{\mathrm{a}}$ \\
\hline 2-IBeA & $1.03 \pm 0.051^{\mathrm{c}, \mathrm{d}}$ & $2.41 \pm 0.112^{b}$ & $0.25 \pm 0.013^{d}$ & $0.15 \pm 0.007^{b}$ & $0.50 \pm 0.024^{\mathrm{d}, \mathrm{e}}$ \\
\hline 2-IBeA+V & $1.03 \pm 0.004^{\mathrm{c}, \mathrm{d}}$ & $3.61 \pm 0.026^{\mathrm{e}}$ & $0.20 \pm 0.001^{b, c}$ & $0.25 \pm 0.001^{\mathrm{g}}$ & $0.55 \pm 0.002^{\mathrm{f}}$ \\
\hline
\end{tabular}

Identical letters in superscript indicate means are not significantly different at $P<0.05$; different letters indicate statistically significant differences at $\mathrm{P} \leq 0.05(n=8)$. The developmental phase of maize: BBCH 15 .

Table 4. Contents of microelements (B, Cu, Fe, Mn, Zn, Mo) in the leaves, shoots, and roots of "Złota Karłowa" sweetcorn at an early stage of development.

\begin{tabular}{|c|c|c|c|c|c|c|}
\hline \multicolumn{7}{|c|}{ Leaves (mg kg ${ }^{-1}$ d.w) } \\
\hline Treatment & B & $\mathrm{Cu}$ & $\mathrm{Fe}$ & Mn & $\mathrm{Zn}$ & Mo \\
\hline Control & $0.85 \pm 0.14^{\mathrm{a}}$ & $15.77 \pm 0.92^{f}$ & $134.91 \pm 4.91^{\mathrm{d}}$ & $104.87 \pm 0.46^{\mathrm{e}}$ & $48.60 \pm 4.54^{\mathrm{d}}$ & $0.04 \pm 0.03^{a, b}$ \\
\hline V & $1.56 \pm 0.41^{b}$ & $14.70 \pm 0.75^{\mathrm{e}}$ & $118.64 \pm 1.21^{\mathrm{c}}$ & $92.65 \pm 0.37^{\mathrm{d}}$ & $40.51 \pm 2.00^{\mathrm{c}}$ & $0.86 \pm 0.12^{a, b}$ \\
\hline KI & $2.29 \pm 0.54^{\mathrm{c}}$ & $11.53 \pm 0.87^{\mathrm{a}, \mathrm{b}}$ & $114.09 \pm 3.03^{c}$ & $65.83 \pm 5.67^{\mathrm{a}}$ & $35.22 \pm 0.94^{\mathrm{a}, \mathrm{b}, \mathrm{c}}$ & $1.31 \pm 0.40^{\mathrm{b}}$ \\
\hline $\mathrm{KI}+\mathrm{V}$ & $1.80 \pm 0.28^{b, c}$ & $11.49 \pm 0.85^{\mathrm{a}}$ & $100.55 \pm 2.45^{\mathrm{a}}$ & $74.22 \pm 3.73^{b, c}$ & $30.53 \pm 1.15^{\mathrm{a}}$ & $1.16 \pm 0.27^{b}$ \\
\hline $\mathrm{KIO}_{3}$ & $1.99 \pm 0.46^{b, c}$ & $12.50 \pm 0.79^{c}$ & $112.65 \pm 2.76^{b, c}$ & $80.73 \pm 6.08^{c}$ & $35.15 \pm 1.22^{\mathrm{a}, \mathrm{b}}$ & $1.08 \pm 0.30^{\mathrm{a}, \mathrm{b}}$ \\
\hline $\mathrm{KIO}_{3}+\mathrm{V}$ & $1.81 \pm 0.42^{b, c}$ & $14.20 \pm 0.93^{\mathrm{d}, \mathrm{e}}$ & $117.84 \pm 3.34^{c}$ & $95.77 \pm 0.50^{\mathrm{d}}$ & $38.96 \pm 1.51^{b, c}$ & $0.56 \pm 0.18^{a, b}$ \\
\hline 5-ISA & $1.99 \pm 0.49^{b, c}$ & $12.43 \pm 0.80^{b, c}$ & $100.93 \pm 2.10^{a}$ & $77.35 \pm 2.37^{b, c}$ & $35.07 \pm 1.28^{\mathrm{a}, \mathrm{b}}$ & $0.79 \pm 0.25^{\mathrm{a}, \mathrm{b}}$ \\
\hline $5-\mathrm{ISA}+\mathrm{V}$ & $1.42 \pm 0.17^{\mathrm{a}, \mathrm{b}}$ & $11.61 \pm 0.91^{\mathrm{a}, \mathrm{b}, \mathrm{c}}$ & $103.91 \pm 1.82^{\mathrm{a}, \mathrm{b}}$ & $71.44 \pm 1.76^{\mathrm{a}, \mathrm{b}}$ & $32.87 \pm 0.43^{a}$ & $0.59 \pm 0.40^{\mathrm{a}, \mathrm{b}}$ \\
\hline 2-IBeA & $1.51 \pm 0.28^{a, b}$ & $11.37 \pm 1.49^{\mathrm{a}}$ & $98.69 \pm 3.95^{\mathrm{a}}$ & $71.25 \pm 2.08^{a, b}$ & $33.15 \pm 2.09^{a}$ & $0.87 \pm 0.32^{a, b}$ \\
\hline 2-IBeA+V & $1.92 \pm 0.39^{b, c}$ & $13.49 \pm 1.18^{\mathrm{d}}$ & $110.52 \pm 5.28^{b, c}$ & $105.93 \pm 4.69^{\mathrm{e}}$ & $46.69 \pm 2.80^{d}$ & $<0.04^{\mathrm{a}}$ \\
\hline \multicolumn{7}{|c|}{ Stems (mg kg ${ }^{-1}$ d.w) } \\
\hline Control & $1.67 \pm 0.46^{g}$ & $12.88 \pm 0.91 \mathrm{~g}$ & $101.77 \pm 4.09^{\mathrm{d}}$ & $54.54 \pm 6.93^{\mathrm{e}}$ & $91.1 \pm 77.31 \mathrm{~g}$ & $<0.04$ \\
\hline $\mathrm{V}$ & $1.46 \pm 0.35^{\mathrm{d}, \mathrm{e}}$ & $10.73 \pm 0.59^{\mathrm{f}}$ & $93.19 \pm 1.19^{\mathrm{c}, \mathrm{d}}$ & $41.78 \pm 2.59^{d}$ & $77.89 \pm 1.17^{f}$ & $<0.04$ \\
\hline KI & $1.33 \pm 0.37^{\mathrm{a}-\mathrm{d}}$ & $8.29 \pm 0.95^{b, c}$ & $76.07 \pm 6.52^{\mathrm{a}}$ & $32.78 \pm 2.40^{b, c}$ & $51.55 \pm 3.06^{\mathrm{a}, \mathrm{b}}$ & $<0.04$ \\
\hline $\mathrm{KI}+\mathrm{V}$ & $1.37 \pm 0.31^{\mathrm{c}, \mathrm{d}, \mathrm{e}}$ & $8.24 \pm 0.66^{b, c}$ & $78.36 \pm 5.21^{\mathrm{a}}$ & $33.52 \pm 0.67^{b, c}$ & $46.92 \pm 3.24^{\mathrm{a}}$ & $<0.04$ \\
\hline $\mathrm{KIO}_{3}$ & $1.34 \pm 0.33^{\mathrm{b}-\mathrm{e}}$ & $9.16 \pm 0.78^{d}$ & $94.52 \pm 0.59^{c, d}$ & $34.47 \pm 1.41^{\mathrm{c}}$ & $66.45 \pm 5.72^{\mathrm{e}}$ & $<0.04$ \\
\hline $\mathrm{KIO}_{3}+\mathrm{V}$ & $1.52 \pm 0.35^{\mathrm{e}, \mathrm{f}}$ & $10.08 \pm 0.77^{\mathrm{e}}$ & $73.41 \pm 5.44^{\mathrm{a}}$ & $34.94 \pm 1.94^{\mathrm{c}}$ & $64.33 \pm 3.86^{\mathrm{d}, \mathrm{e}}$ & $<0.04$ \\
\hline 5-ISA & $1.30 \pm 0.31^{\mathrm{a}-\mathrm{d}}$ & $8.72 \pm 0.56^{\mathrm{c}, \mathrm{d}}$ & $80.17 \pm 2.52^{a, b}$ & $31.23 \pm 0.25^{b}$ & $59.43 \pm 3.48^{c, d}$ & $<0.04$ \\
\hline $5-\mathrm{ISA}+\mathrm{V}$ & $1.18 \pm 0.29^{a, b, c}$ & $7.71 \pm 0.51^{\mathrm{a}}$ & $71.09 \pm 6.99^{a}$ & $28.65 \pm 0.40^{\mathrm{a}}$ & $49.65 \pm 2.05^{\mathrm{a}}$ & $<0.04$ \\
\hline 2-IBeA & $1.15 \pm 0.28^{\mathrm{a}, \mathrm{b}}$ & $7.89 \pm 0.98^{a, b}$ & $89.24 \pm 2.13^{b, c}$ & $31.46 \pm 1.90^{b}$ & $55.77 \pm 5.56^{b, c}$ & $<0.04$ \\
\hline 2-IBeA+V & $1.13 \pm 0.28^{\mathrm{a}}$ & $9.97 \pm 0.77^{\mathrm{e}}$ & $94.20 \pm 4.54^{\mathrm{c}, \mathrm{d}}$ & $41.45 \pm 0.61^{\mathrm{d}}$ & $94.22 \pm 1.44 \mathrm{~g}$ & $<0.04$ \\
\hline \multicolumn{7}{|c|}{ Roots (mg kg ${ }^{-1}$ d.w) } \\
\hline Control & $1.74 \pm 0.03^{b}$ & $36.74 \pm 0.40^{f}$ & $146.66 \pm 10.51^{\mathrm{e}, \mathrm{f}}$ & $52.62 \pm 0.33^{d}$ & $63.91 \pm 0.32^{\mathrm{d}}$ & $1.11 \pm 0.04^{\mathrm{a}, \mathrm{b}, \mathrm{c}}$ \\
\hline V & $1.49 \pm 0.03^{\mathrm{a}}$ & $20.42 \pm 0.19^{e}$ & $116.55 \pm 1.20^{b, c}$ & $32.39 \pm 0.21^{b}$ & $96.25 \pm 0.93^{\mathrm{e}}$ & $1.36 \pm 0.05^{c}$ \\
\hline KI & $1.66 \pm 0.02^{a, b}$ & $17.32 \pm 0.15^{\mathrm{c}}$ & $138.62 \pm 0.43^{\mathrm{d}, \mathrm{e}, \mathrm{f}}$ & $50.45 \pm 2.12^{d}$ & $61.58 \pm 0.33^{c, d}$ & $1.18 \pm 0.15^{b, c}$ \\
\hline $\mathrm{KI}+\mathrm{V}$ & $1.59 \pm 0.04^{\mathrm{a}, \mathrm{b}}$ & $14.50 \pm 0.04^{\mathrm{a}}$ & $153.51 \pm 0.78^{\mathrm{f}}$ & $35.24 \pm 0.34^{b}$ & $59.24 \pm 0.40^{c}$ & $0.76 \pm 0.06^{\mathrm{a}}$ \\
\hline $\mathrm{KIO}_{3}$ & $1.50 \pm 0.04^{\mathrm{a}}$ & $19.41 \pm 0.69 \mathrm{~d}, \mathrm{e}$ & $129.04 \pm 4.64^{\mathrm{c}, \mathrm{d}, \mathrm{e}}$ & $41.60 \pm 1.42^{c}$ & $44.18 \pm 1.34^{b}$ & $0.95 \pm 0.05^{\mathrm{a}, \mathrm{b}, \mathrm{c}}$ \\
\hline $\mathrm{KIO}_{3}+\mathrm{V}$ & $1.66 \pm 0.07^{\mathrm{a}, \mathrm{b}}$ & $18.33 \pm 0.07^{\mathrm{c}, \mathrm{d}}$ & $120.39 \pm 0.95^{b, c, d}$ & $43.28 \pm 0.36^{c}$ & $46.95 \pm 0.27^{b}$ & $0.90 \pm 0.04^{\mathrm{a}, \mathrm{b}}$ \\
\hline 5-ISA & $1.63 \pm 0.02^{a, b}$ & $14.15 \pm 0.11^{\mathrm{a}}$ & $100.09 \pm 0.46^{\mathrm{a}, \mathrm{b}}$ & $31.01 \pm 0.20^{b}$ & $44.78 \pm 0.49^{b}$ & $0.88 \pm 0.06^{a, b}$ \\
\hline $5-\mathrm{ISA}+\mathrm{V}$ & $1.45 \pm 0.09^{\mathrm{a}}$ & $15.55 \pm 0.06^{\mathrm{a}, \mathrm{b}}$ & $108.35 \pm 1.00^{\mathrm{a}, \mathrm{b}, \mathrm{c}}$ & $23.06 \pm 0.22^{a}$ & $37.76 \pm 0.31^{\mathrm{a}}$ & $1.03 \pm 0.10^{\mathrm{a}, \mathrm{b}, \mathrm{c}}$ \\
\hline 2-IBeA & $1.48 \pm 0.04^{\mathrm{a}}$ & $14.61 \pm 0.67^{a}$ & $122.83 \pm 6.42^{c, d}$ & $32.19 \pm 1.57^{b}$ & $35.42 \pm 1.37^{\mathrm{a}}$ & $1.00 \pm 0.14^{\mathrm{a}, \mathrm{b}, \mathrm{c}}$ \\
\hline 2-IBeA+V & $1.46 \pm 0.03^{\mathrm{a}}$ & $16.71 \pm 0.12^{b, c}$ & $91.29 \pm 3.11^{\mathrm{a}}$ & $89.66 \pm 0.50^{\mathrm{e}}$ & $43.45 \pm 0.19^{b}$ & $0.70 \pm 0.06^{\mathrm{a}}$ \\
\hline
\end{tabular}

Identical letters in superscript indicate means are not significantly different at $P<0.05$; different letters indicate statistically significant differences at $\mathrm{P} \leq 0.05(n=8)$. The developmental phase of maize: $\mathrm{BBCH} 15$. 
Compared to the control, almost all tested treatments of vanadium and iodine compounds (applied separately and in combination in vanadium) reduced the contents of the following elements: $\mathrm{Ca}$ and $\mathrm{Mg}$ in stems and leaves; $\mathrm{K}$ and $\mathrm{S}$ in leaves; $\mathrm{P}, \mathrm{Cu}, \mathrm{Fe}, \mathrm{Mn}, \mathrm{Zn}$ in roots, stems, and leaves; $\mathrm{B}$ in roots and stems; and Mo in roots (Tables 3 and 4); whereras B and Mo contents were increased in leaves. In contrast, $\mathrm{Ca}$ content increased in leaves, $\mathrm{Zn}$ increased in shoots, and Mn increased in roots, which was significant after fertilization with $2 \mathrm{IBe} A+\mathrm{V}$.

Application of $\mathrm{KI}$ alone resulted in plants with the lowest contents of all tested treatments, i.e., $\mathrm{Ca}$, $\mathrm{Mg}$, B, and $\mathrm{Mn}$ in leaves and $\mathrm{Ca}$ in stems. Further, $\mathrm{KI}+\mathrm{V}$ application resulted in plants with the lowest $\mathrm{P}$ and $\mathrm{Zn}$ contents in leaves, as well as $\mathrm{K}, \mathrm{Mg}, \mathrm{P}, \mathrm{S}$, and $\mathrm{Zn}$ in stems. The exogenous use of 5-ISA+V caused the largest reduction in the contents of $\mathrm{K}, \mathrm{P}, \mathrm{S}, \mathrm{B}$, and $\mathrm{Mn}$ in maize roots.

\section{Discussion}

In the present study, the application of 5-ISA+V and KI+V stimulated root system growth and development and, in the case of $\mathrm{KI}+\mathrm{V}$, also aerial part mass of maize plants. This may be due to the contribution of vanadium to nitrogen metabolism, whereby vanadium functions as a growth-stimulating factor and is involved in the binding and accumulation of nitrogen in plants [55]. The impact of organic iodine compounds on sweetcorn plants is not well known. After application of 2-IBeA $+V$, the highest concentrations of iodine in shoots was observed. 2-IBeA can be taken up by plants [16] and can also be precursor of 2,3,5-tri-iodobenzoic acid in plants [52], which is an inhibitor of auxin transport. This may be why decreased plant height and weight after 2-IBeA+V application was observed in this work.

Yang's [56] research on soybeans using different concentrations of vanadium (V) showed that the lowest doses used to stimulate the development of the soybean root system in early development were 0.05 and $0.10 \mathrm{mM} \mathrm{V}$. In our research, vanadium applied with 2-IBeA (2-IBeA+V) showed a different effect on root development compared to the use of 5-ISA+V and KI+V. Research conducted by Halka et al. [57] showed that tomato plant biomass decreased after 2-IBeA treatment.

Transport and uptake of iodine through plant roots can flow actively or passively [58]. Significant differences in both iodine content and uptake were noted between the tested treatments in corn leaves, roots, and shoots. The highest content was recorded in the roots after application of $\mathrm{KIO}_{3}+\mathrm{V}$. Furthermore, it was found that corn roots preferentially uptake $\mathrm{IO}_{3}{ }^{-}$over $\mathrm{I}^{-}$. These observations were different from the preferential $\mathrm{I}^{-}$uptake over $\mathrm{IO}_{3}{ }^{-}$generally described in the literature [47,59]. Smolen et al. [53] obtained similar results. The application of $\mathrm{KIO}_{3}$ with humic and fulvic acid caused higher concentrations of iodine in spinach leaves compared to KI complexed with humic and fulvic acid. $\mathrm{KIO}_{3}$ may be reduced to $\mathrm{I}_{2}$ and bind aromatic rings from organic matter compounds, causing easier and more effective uptake by plants. Oxidation of $\mathrm{I}^{-}$to $\mathrm{I}_{2}$ occurs at different redox potential levels and lower $\mathrm{pH}$ levels more suitable to the $\mathrm{IO}_{3}{ }^{-}$form.

Distribution of iodine described in the literature in plant parts is as follows: roots $>$ leaves $>$ stem $>$ fruit [2]. In our experiment, the highest concentration of iodine was obtained according to this scheme. The concentration of iodine in combination with $\mathrm{KIO}_{3}+\mathrm{V}$ in roots was four times higher compared to the concentration of iodine with this combination found in leaves.

Generally, iodine accumulation in aerial plant parts was lower than in corn roots. However, the level of uptake of iodine was as high as in roots, with iodine uptake by stems being minimal. This was probably because of the much greater leaf mass per plant than root mass (dilution effect of iodine in leaf).

Information regarding the beneficial effects of vanadium on plants and animals exists widely in the literature, with the objection that concentrations of this element are used in trace doses [60]. Vanadium uptake is dependent on $\mathrm{pH}$, with increased vanadium uptake observed at low $\mathrm{pH}$ (less than 4) and uptake in the range of 5 to 8 reduced but stabilized. The use of peat substrate in the current experiment with a $\mathrm{pH}$ range of 5.5 to 6.0 represents an acceptable level for uptake enhancement. The application of vanadium (without any iodine compounds) caused higher concentrations in the roots, 
but transport to stems and leaves was not effective. High $\mathrm{pH}$ (alkaline) hindered vanadium uptake in oat roots [60].

Vachirapatama et al. [26] conducted research on Chinese green mustard and tomato. The increasing doses of vanadium applied (i.e., in the range of $1 \mathrm{mg} \cdot \mathrm{dm}^{-3}$ to $80 \mathrm{mg} \cdot \mathrm{dm}^{-3}$ ) caused a gradual decrease in the development of the root system, reducing the mass and length of plants. Similar results were observed in chickpea, with vanadium caused a significant decrease in the mass of roots and aerial parts [61]. Corresponding results were obtained in bean, in which the use of vanadium compounds caused improper development of the main root and development inhibition of the lateral roots [62]. However, Chongkid et al. [63] showed a stimulating effect of vanadium at a dose of $10 \mathrm{mg} \cdot \mathrm{dm}^{-3} \mathrm{on}^{-}$ rice shoot growth, indicating the possibility of a stimulating effect of vanadium on the growth and development of individual species in low doses.

The application of vanadium resulted in higher contents in the stems, leaves, and roots of Chinese mustard and tomato [26]. The results of our research did not show such significant differences in vanadium content between parts of plants (roots, shoots, and leaves), demonstrating different results compared to the works by Vachirapatama et al. [26], Imtiaz [61], and Saco [62]. This may be due to mineral nutrition functioning of plants relative to vanadium. Nevertheless, lower doses of vanadium showed a stimulating effect in the early developmental stage of corn plants.

Almost all of the vanadium treatments and iodine compounds (applied separately and in combination with vanadium) in this research demonstrated a negative impact on mineral nutrition functioning and micronutrient and macronutrient concentrations in sweetcorn compared to the control (without iodine and vanadium). Plant fertilization with $\mathrm{KI}$ (in terms of $\mathrm{Ca}, \mathrm{Mg}$, B, and Mn contents in leaves and $\mathrm{Ca}$ in stems) unfavorably affected the mineral nutrition of plants (and thus the contents of macronutrients and micronutrients), followed by $\mathrm{KI}+\mathrm{V}$ (in the content of $\mathrm{P}$ and $\mathrm{Zn}$ in leaves as well as $\mathrm{K}, \mathrm{Mg}, \mathrm{P}, \mathrm{S}$, and $\mathrm{Zn}$ in stems) and, to a lower extent, 5-ISA+V (K, P, S, B, and Mn contents in corn roots). Comparison of pairs of treatments with vanadium fertilization compared to treatments without the use of this element (control versus $\mathrm{V}$, as well as all iodine treatments versus all iodine treatments $+\mathrm{V}$ ) showed that vanadium, depending on the form of iodine used, exerted variable effects on the contents of macro elements and microelements in the roots, shoots, and leaves of corn, causing significant increases, decreases or not affecting individual macro element and microelement concentrations in maize plants. Therefore, it is impossible to clearly determine mineral nutrition process functioning of corn plants depending on fertilization according to vanadium and vanadium plus $\mathrm{KI}, \mathrm{KIO}_{3}, 5-\mathrm{ISA}_{\text {, }}$ or 2-IBeA.

Changes in the contents of mineral elements in parts of plants after iodine application depended highly on the dose and form of iodine used [64]. Iodine can antagonistically or synergistically impact on the uptake of macroelements and microelements [65]. Smolen and Sady [65] conducted research in iodine-biofortified spinach, showing increased uptake and accumulation of $\mathrm{Mg}, \mathrm{Na}, \mathrm{Ce}$, and Fe at a dose of $1 \mathrm{mg} \mathrm{I} \mathrm{dm}^{-3}$. A higher dose of iodine at $2 \mathrm{mg} \mathrm{I} \cdot \mathrm{dm}^{-3}$ caused increases in the contents of $\mathrm{Na}$, $\mathrm{Fe}, \mathrm{Zn}$, and $\mathrm{Al}$ in spinach leaves and decreased contents of $\mathrm{P}, \mathrm{S}, \mathrm{Cu}$, and $\mathrm{Ba}$.

The dose of vanadium used has a decisive impact on the mineral plant nutrition process. Akoumianaki-Ioannidou et al. [28] noted a decrease in the contents of $\mathrm{K}, \mathrm{Fe}, \mathrm{Zn}$, and $\mathrm{Pb}$ in leaves and $\mathrm{K}, \mathrm{Fe}, \mathrm{Mn}, \mathrm{Zn}$, and $\mathrm{Pb}$ in basil roots after vanadium fertilization in the dose range of 5-40 $\mathrm{mg}$ $\mathrm{V} \cdot \mathrm{dm}^{-3}$ substrate. Based on the literature, a positive effect of vanadium is that it allows for better utilization of potassium [66]. The combination of vanadium with the organic form of iodine 2-IBeA showed a positive effect on potassium content in leaves, roots, and stems. Iodine (2IBeA) combined with vanadium increased contents of potassium in roots and stems by around $50 \%$ compared to 2-IBeA application.

In the case of soybean plants, the contents of $\mathrm{N}, \mathrm{P}, \mathrm{Mg}, \mathrm{Fe}$, and $\mathrm{B}$ in roots and leaves were shaped

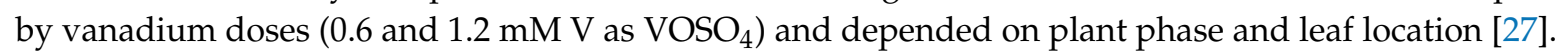
In soybean plants, vanadium was observed to stimulate increases in $\mathrm{K}$ and Mn contents in leaves 
while simultaneously reducing its content in the roots. In addition, Kaplan et al. [27] observed an antagonistic effect of vanadium on the content of $\mathrm{Ca}$ in roots and $\mathrm{Cu}, \mathrm{Zn}$, and $\mathrm{Mo}$ in roots and leaves.

\section{Conclusions}

Ammonium metavanadate fertilization significantly improved the growth of sweetcorn. The applied dose of vanadium and iodine compounds did not demonstrate any toxicity to sweetcorn plants. Iodine and vanadium fertilization increased the iodine contents of plants. The theory of poor vanadium transport from roots to above-ground plant parts was also confirmed. The greatest accumulation of vanadium was observed in the roots. Iodine and vanadium application resulted in higher concentrations of iodine in all applied combinations. The highest iodine content in the leaves was obtained after applying an organic form of iodine alongside vanadium. In the roots, greater accumulation of iodine was achieved by combining it with an inorganic form of vanadium. Based on the concentration of iodine in the roots and higher parts of the plant, transport of the organic form of iodine is more efficient than inorganic forms in sweetcorn. The application of iodine and vanadium significantly changed the mineral nutrition status of maize at an early developmental stage. Extenuation of macronutrient and micronutrient uptake in plants with iodine and vanadium fertilization was observed.

Supplementary Materials: The following are available online at http://www.mdpi.com/2073-4395/10/11/1666/s1. Table S1 Dry matter content in sweet corn plants parts (roots, stems, leaves).

Author Contributions: Conceptualization, S.S.; methodology, S.S. and M.G.; formal analysis, M.G.; investigation, M.G. and S.S.; resources, S.S..; data curation, M.G.; writing-original draft preparation, M.G. and S.S.; writing—review and editing, P.K.; visualization, M.G.; supervision, S.S.; project administration, S.S.; funding acquisition, S.S. and P.K. All authors have read and agreed to the published version of the manuscript.

Funding: This research was funded by the subvention from the Polish Ministry of Science and Higher Education for the University of Agriculture in Krakow.

Conflicts of Interest: The authors declare no conflict of interest.

\section{References}

1. Lazarus, J.H. The importance of iodine in public health. Environ. Geochem. Health 2015, 37, 605-618. [CrossRef] [PubMed]

2. Weng, H.T.; Hong, C.L.; Xia, T.H.; Baao, L.T.; Liu, H.P.; Li, D.W. Iodine biofortification of vegetable plants-An innovative method for iodine supplementation. Chin. Sci. Bull. 2013, 58, 2066-2072. [CrossRef]

3. Zimmermann, M.B. Iodine Deficiency. Endocr. Rev. 2009, 30, 376-408. [CrossRef] [PubMed]

4. Mohammadi, M.; Azizi, F.; Hedaya, M. Iodine deficiency status in the WHO Eastern MediterraneanRegion: A systematic review. Environ. Geochem. Health 2018, 40, 87-97. [CrossRef] [PubMed]

5. Blasco, B.; Rios, J.J.; Cervilla, L.M.; Sánchez-Rodrigez, E.; Ruiz, J.M.; Romero, L. Iodine biofortification and antioxidant capacity of lettuce: Potential benefits for cultivation and human health. Ann. Appl. Biol. 2008, 152, 289-299. [CrossRef]

6. Smolen, S.; Kowalska, I.; Sady, W. Assesment of biofortyfication with iodine and selenium of lettuce cultivated in the NFT hydroponic system. Sci. Hortic. 2014, 166, 9-16. [CrossRef]

7. Zhu, Y.G.; Huang, Y.Z.; Hu, Y.; Liu, Y.X. Iodine uptake by spinach (Spinacia oleracea L.) plants grown in solution culture: Effect of iodine species and solution concentrations. Environ. Int. 2003, 29, 33-37. [CrossRef]

8. Dai, J.L.; Zhu, Y.G.; Huang, Y.Z.; Zang, M.; Song, J.L. Availability of iodide and iodate to spinach (Spinacia oleracea L.) in relation to total iodine in soil solution. Plant Soil 2006, 289, 301-308. [CrossRef]

9. Landini, M.; Gonzali, S.; Perata, P. Iodine biofortification in tomato. J. Plant Nutr. Soil Sci. 2011, 174, 480-486. [CrossRef]

10. Weng, H.X.; Yan, A.L.; Hong, C.L.; Xie, L.L.; Qin, Y.C.; Cheng, C.Q. Uptake of different species of iodine by water spinach and its effect to growth. Biol. Trace Elem. Res. 2008, 124, 184-194. [CrossRef] [PubMed]

11. Dai, J.L.; Zhu, Y.G.; Zhang, M.; Huang, Y.Z. Selecting iodine-enriched vegetables and the residual effect of iodate application to soil. Biol. Trace Elem. Res. 2004, 101, 265-276. [CrossRef] 
12. Smoleń, S.; Kowalska, I.; Skoczylas, Ł.; Liszka-Skoczylas, M.; Grzanka, M.; Halka, M.; Sady, W. The effect of salicylic acid on biofortification with iodine and selenium and the quality of potato cultivated in the NFT system. Sci. Hortic. 2018, 240, 530-543. [CrossRef]

13. Maćkowiak, C.L.; Grossl, P.R. Iodate and iodide effects on iodine uptake and partitioning in rice (Oryza sativa L.) grown in solution culture. Plant Soil 1999, 212, 133-141.

14. Cakmak, I.; Prom-u-Thai, C.; Guliherme, L.R.G.; Rashid, A.; Hora, K.H.; Yazici, A.; Savasli, E.; Kalayci, M.; Tutus, Y.; Phuphong, P.; et al. Iodine biofortification of wheat, rice and maize through fertilizer strategy. Plant Soil 2017, 418, 319-335. [CrossRef]

15. Germ, M.; Stibilj, V.; Šircelj, H.; Jerše, A.; Kroflič, A.; Golob, A.; Maršić, N.K. Biofortification of common buckwheat microgreens and seeds with different forms of selenium and iodine. J. Sci. Food Agric. 2019, 99, 4353-4362. [CrossRef] [PubMed]

16. Halka, M.; Smoleń, S.; Czernicka, M.; Klimek-Chodacka, M.; Pitala, J.; Tutaj, K. Iodine biofortification through expression of HMT, SAMT and S3H genes in Solanum lycopersicum L. Plant Physiol. Biochem. 2019, 144, 35-48. [CrossRef] [PubMed]

17. Sularz, O.; Smoleń, S.; Koronowicz, A.; Kowalska, I.; Leśzczyńska, T. Chemical composition of lettuce (Lactuca sativa L.) biofortified with iodine by $\mathrm{KIO}_{3}, 5$-iodo-, and 3.5-diiodosalicylic acid in a hydroponic cultivation. Agronomy 2020, 10, 1022. [CrossRef]

18. Lawson, P.G.; Daum, D.; Czauderna, R.; Meuser, H.; Hartling, J.W. Soil versus foliar iodine fertilization as a biofortification strategy for field-grown vegetables. Front. Plant Sci. 2015, 6, 450. [CrossRef]

19. Fuge, R. Geochemistry of iodine in relation to iodine deficiency diseases. Geol. Soc. 1996, 113, $201-211$. [CrossRef]

20. Leblanc, C.; Colin, C.; Cosse, A.; Delage, L.; la Barre, S.; Morin, P.; Fiévet, B.; Voiseux, C.; Ambroise, Y.; Verhaeghe, E.; et al. Iodine transfers in the coastal marine environment: The key role of brown algae and of their vanadium-dependent haloperoxidases. Biochemie 2006, 88, 1773-1785. [CrossRef]

21. Küpper, F.C.; Schweigert, N.; Ar Gall, E.; Legendre, J.M.; Vilter, H.; Kloareg, B. Iodine uptake in Laminariales involves extracellular. haloperoxidase-mediated oxidation of iodide. Planta 1998, 207, 163-171.

22. Tymon, T.M.; Miller, E.P.; Gonzalez, J.L.; Raab, A.; Kupper, F.C.; Carrano, C.J. Some aspects of the iodine metabolism of the giant kelp Macrocystis pyrifera (phaeophyceae). J. Inorg. Biochem. 2017, 177, 82-88. [CrossRef] [PubMed]

23. Butler, A.; Carter-Franklin, J.N. The role of vanadium bromoperoxidase in the biosynthesis of halogenated marine natural products. Nat. Prod. Rep. 2004, 21, 180-188. [CrossRef] [PubMed]

24. Medrano-Macías, J.; Leija-Martínez, P.; González-Morales, S.; Juárez-Maldonado, A.; Benavides-Mendoza, A. Use of iodine to biofortify and promote growth and stress tolerance in crops. Front. Plant Sci. 2016, 7, 1146. [CrossRef] [PubMed]

25. Roberts, G.K.; Stout, M.D.; Sayers, B.; Fallacar, D.M.; Hejtmancik, M.R.; Waidyanatha, S.; Hooth, M. 14 day toxicity studies of tetravalent and pentavalent vanadium compounds in Harlan Sprague Dawley rats and B6C3F1/N mice via drinking water exposure. Toxicol. Rep. 2016, 3, 531-538. [CrossRef]

26. Vachirapatama, N.; Jirakiattikul, Y.; Dicinoski, G.; Townsend, A.T.; Haddad, P.R. Effect of vanadium on plant growth and its accumulation in plant tissues. Songklanakarin J. Sci. Technol. 2011, 33, 255-261.

27. Kaplan, D.I.; Adriano, D.C.; Carlson, C.L.; Sajwan, K.S. Vanadium: Toxicity and accumulation by beans. Water. Air. Soil Pollut. 1990, 49, 81-91. [CrossRef]

28. Akoumianaki-Ioannidou, A.; Barouchas, P.E.; Ilia, E.; Kyramariou, A.; Moustakas, N.K. Effect of vanadium on dry matter and nutrient concentration in sweet basil (Ocimum basilicum L.). Aust. J. Crop Sci. 2016, 10, 199.

29. Vara, F.; Serrano, R. Partial purification and properties of the proton-translocating ATPase of plant plasma membranes. J. Biol. Chem. 1982, 257, 12826-12830. [PubMed]

30. Wdowikowska, A.; Kłobus, G. Plant P-type ATPases. Postępy Biochem. 2011, 57, 85-91.

31. Karoń, B. Doświadczenie wazonowe nad wpływem wanadu na plon i skład chemiczny niektórych roślin. Rocz. Glebozn. 1977, 28, 155-172.

32. Akoumianaki Ioannidou, A.; Barouchas, P.E.; Kyramariou, A.; Ilia, E.; Moustakas, N.K. Effect of vanadium on dry matter and nutrient concentration in pennyroyal (Mentha pulegium L). Bull. UASVM Hortic. 2015, 72, 295-298. [CrossRef]

33. Evangelou, A.M. Vanadium in cancer treatment. Crit. Rev. Oncol. Hematol. 2002, 42, 249-265. [CrossRef] 
34. Srivastava, A.K.; Mehdi, M.Z. Insulino-mimetic and anti-diabetic effects of vanadium compounds. Diabet. Med. 2005, 22, 2-13. [CrossRef] [PubMed]

35. Panchal, S.K.; Wanyonyi, S.; Brown, L. Selenium, Vanadium, and Chromium as Micronutrients to Improve Metabolic Syndrome. Curr. Hypertens. Rep. 2017, 19, 10. [CrossRef] [PubMed]

36. Urban, J.; Antonowicz-Juchniewicz, J.; Andrzejak, R. WANAD—ZAGROŻENIA I NADZIEJE. Med. Pr. 2001, 52, 125-133. [PubMed]

37. Barceloux, D.G.; Barceloux, D. Vanadium. J. Toxicol. Clin. Toxicol. 1999, 37, 265-278. [CrossRef] [PubMed]

38. Mukherjee, B.; Patra, B.; Mahapatra, S.; Banerjee, P.; Tiwari, A.; Chatterjee, M. Vanadium-An element of atypical biological significance. Toxicol. Lett. 2009, 150, 135-143. [CrossRef] [PubMed]

39. Gruzewska, K.; Michno, A.; Pawelczyk, T.; Bielarczyk, H. Essentiality and toxicity of vanadium supplements in health and pathology. J. Physiol. Pharmacol. 2014, 65, 603-611.

40. Boden, G.; Chen, X.; Ruiz, J.; van Rossum, G.D.V.; Turco, S. Effects of vanadyl sulfate on carbohydrate and lipid metabolism in patients with non-insulin-dependent diabetes mellitus. Metabolism 1996, 45, 1130-1135. [CrossRef]

41. Nielsen, F.H.; Uthus, E.O. The Essentiality and Metabolism of Vanadium. In Physiology and Biochemistry; Kluwer Academic Publishers: Amsterdam, The Netherlands, 1990; pp. 51-62.

42. WHO. Vanadium Pentoxide and Other Inorganic Vanadium Compounds; The World Health Organization: Geneva, Switzerland, 2001.

43. Thumbo, P.; Yates, A.A.; Schlicker, S.; Poos, M. Dietary Reference Intakes: Vitamin, A, viramin K, Arsenic, Boron, Chromium, Copper, Iodine, Iron. Manganese, Molybdenum, Nickle, Silicon, Vanadium, and Zinc. J. Am. Diet. Assoc. 2001, 3, 294-301.

44. Leyva, R.; Sánchez-Rodríguez, E.; Ríos, J.J.; Rubio-Wilhelmi, M.M.; Romero, L.; Ruiz, J.M.; Blasco, B. Beneficial effects of exogenous iodine in lettuce plants subjected to salinity stress. Plant Sci. 2011, 181, 195-202. [CrossRef] [PubMed]

45. Gupta, N.; Bajpai, M.; Majumdar, R.; Mishra, P. Response of iodine on antioxidant levels of Glycine max L. Grown under $\mathrm{Cd}^{2+}$ stress. Adv. Biol. Res. 2015, 9, 40-48.

46. Matsugo, S.; Kanamori, K.; Sugiyama, H.; Misu, H.; Takamura, T. Physiological roles of peroxido-vanadium complexes: Leitmotif as their signal transduction pathway. J. Inorg. Biochem. 2015, 147, 9398. [CrossRef] [PubMed]

47. Caffagni, A.; Pecchioni, N.; Meriggi, P.; Bucci, V.; Sabatini, E.; Acciarri, N.; Ciriaci, T.; Pulcini, L.; Felicioni, N.; Beretta, M.; et al. Iodine uptake and distribution in horticultural and fruit tree species. Ital. J. Agron. 2012, 7, e32. [CrossRef]

48. Gonzali, S.; Kiferle, C.; Perata, P. Iodine biofortification of crops: Agronomic biofortification, metabolic engineering and iodine bioavailability. Curr. Opin. Biotechnol. 2017, 44, 16-26. [CrossRef]

49. Hong, C.L.; Weng, H.X.; Yan, A.L.; Islam, E.U. The fate of exogenous iodine in pot soil cultivated with vegetables. Environ. Geochem. Health 2009, 31, 99-108. [CrossRef]

50. McLauchlana, C.C.; Murakamib, H.A.; Wallacea, C.A.; Crans, D.C. Coordination environment changes of the vanadium in vanadium-dependenthaloperoxidase enzymes. J. Inorg. Biochem. 2018, 186, 267-279. [CrossRef]

51. Timmins, A.; Visser, S.P. Enzymatic halogenases and haloperoxidases: Computational studies on mechanism and function. Adv. Protein Chem. Struct. Biol. 2015, 100, 113-151.

52. Smoleń, S.; Kowalska, I.; Halka, M.; Ledwożyw-Smoleń, I.; Grzanka, M.; Skoczylas, Ł.; Czernicka, M.; Pitala, J. Selected aspects of iodate and iodosalicylate metabolism in lettuce including the activity of vanadium dependent haloperoxidases as affected by exogenous vanadium. Agronomy 2019, 10, 1. [CrossRef]

53. Smoleń, S.; Ledwożyw-Smoleń, I.; Sady, W. The role of exogenous humic and fulvic acids in iodine biofortification in spinach (Spinacia oleracea L.). Plant Soil 2016, 402, 129-143.

54. Pasławski, P.; Migaszewski, Z.M. The quality of element determinations in plant materials by instrumental methods. Pol. J. Environ. Stud. 2006, 15, 154-164.

55. Taylor, M.J.C.; Saden, J.F. Spectrophotometric determination of vanadium(IV) and vanadium(V) in each other's presence. Analyst 1994, 119, 1263-1276. [CrossRef]

56. Yang, J.; Wang, M.; Jia, Y.; Gou, M.; Zeyer, J. Toxicity of vanadium in soil on soybean at different growth stages. Environ. Pollut. 2017, 231, 48e58. [CrossRef] [PubMed] 
57. Halka, M.; Klimek-Chodacka, M.; Smoleń, S.; Baranski, R.; Ledwożyw-Smoleń, I.; Sady, W. Organic iodine supply affects tomato plants differently than inorganic iodine. Physiol. Plant. 2018, 164, 290-306. [CrossRef] [PubMed]

58. Sarma, H. Metal hyperaccumulation in plants: A revive focusing on phytoremediation technology. J. Environ. Sci. Technol. 2011, 4, 118-138. [CrossRef]

59. Voogt, W.; Holwerda, H.T.; Khodabaks, R. Biofortification of lettuce (Lactuca sativa L.) with iodine: The effect of iodine form and concentration in the nutrient solution on growth. development and iodine uptake of lettuce grown in water culture. J. Sci. Food Agric. 2010, 90, 906-913. [CrossRef]

60. Welch, R.M.; Huffman, E.W. Vanadium and plant nutrition: The growth of lettuce (Lactuca sativa L.) and Tomato (Lycopersicon esculentum Mill.) plants in nutrient solutions low in vanadium. Plant Physiol. 1973, 52, 183-185. [CrossRef]

61. Imtiaz, M.; Ashraf, M.; Rizwan, M.S.; Nawaz, M.A.; Rizwan, M.; Mehmood, S.; Ali, M. Vanadium toxicity in chickpea (Cicer arietinum L.) grown in red soil: Effects on cell death. ROS and antioxidative systems. Ecotoxicol. Environ. Saf. 2018, 158, 139-144. [CrossRef]

62. Saco, D.; Martín, S.; San José, P. Vanadium distribution in roots and leaves of Phaseolus vulgaris: Morphological and ultrastructural effects. Biol. Plant. 2013, 57, 128-132. [CrossRef]

63. Chongkid, B.; Vachirapatama, N.; Jirakiattikul, Y. Effects of V on rice growth and vandium accumulation in rice tissues. Kasetsart J. 2007, 41, 28-33.

64. Krzepiłko, A.; Zych-Wężyk, I.; Święciło, A.; Molas, J.; Skwaryło-Bednarz, B. Effect of iodine biofortification of lettuce seedlings on their mineral composition and biological quality. J. Elem. 2016, 21, 1071-1080. [CrossRef]

65. Smoleń, S.; Sady, W. Influence of iodine form and application method on the effectiveness of iodine biofortification, nitrogen metabolism as well as the content of mineral nutrients and heavy metals in spinach plants (Spinacia oleracea L.). Sci. Hortic. 2012, 143, 176-183.

66. Imtiaz, M.; Rizwan, M.S.; Xiong, S.; Li, H.; Ashraf, M.; Shahzad, S.M.; Shahzad, M.; Rizwan, M.; Tu, S. Vanadium, recent advancements and research prospects: A review. Environ. Int. 2015, 80, 79-88. [CrossRef] [PubMed]

Publisher's Note: MDPI stays neutral with regard to jurisdictional claims in published maps and institutional affiliations.

(C) 2020 by the authors. Licensee MDPI, Basel, Switzerland. This article is an open access article distributed under the terms and conditions of the Creative Commons Attribution (CC BY) license (http://creativecommons.org/licenses/by/4.0/). 